\title{
Relationship Lending in the Interbank Market and the Price of Liquidity
}

\author{
Falk Bräuning and Falko Fecht
}

\begin{abstract}
We empirically investigate the effect that relationship lending has on the availability and pricing of interbank liquidity. Our analysis is based on a daily panel of unsecured overnight loans between 1,079 distinct German bank pairs from March 2006 to November 2007, a period that includes the 2007 liquidity crisis that marked the beginning of the 2007/08 global financial crisis. We find that (i) relationship lenders are more likely to provide liquidity to their closest borrowers, (ii) particularly opaque borrowers obtain liquidity at lower rates when borrowing from their relationship lenders, and (iii) during the crisis, relationship lenders provided cheaper loans to their closest borrowers. Our results hold after controlling for search frictions as well as a large set of (time-varying) bank and bank-pair control variables and fixed effects. While we find some indication that lending relationships help banks reduce search frictions in the over-the-counter interbank market, our results establish that bank-pair relationships have a significant impact on interbank credit availability and pricing due to mitigating uncertainty about counterparty credit quality.
\end{abstract}

Keywords: interbank market, relationship lending, financial crisis, central counterparty, financial contagion

JEL Classifications: D61, E44, G10, G21

Falk Bräuning is an economist in the research department at the Federal Reserve Bank of Boston. His e-mail address is falk.brauening@bos.frb.org. Falko Fecht is the DZ Bank Endowed Chair of Financial Economics at the Frankfurt School of Finance and Management. His e-mail address is f.fecht@fs.de.

We thank Diego Cerdeiro, Valeriya Dinger, Heinz Herrmann, Achim Hauck, André Lucas, Albert Menkveld, Cyril Monnet, Ulrike Neyer, Joe Peek, Klaus Schaeck, Viktors Stebunovs, Günseli Tümar-Alkan, and Sweder van Wijnbergen. We also thank seminar and workshop participants at the Central Bank of Luxembourg, Deutsche Bundesbank, European Central Bank, Norges Bank, University of Dusseldorf, University of Osnabrück, Tinbergen Institute, VU University Amsterdam, WHU-Beisheim School of Management, and Universitat Jaime I for valuable comments. We are grateful to the Research Centre of the Deutsche Bundesbank for data access and hospitality.

This paper presents preliminary analysis and results intended to stimulate discussion and critical comment. The views expressed herein are those of the authors and do not indicate concurrence by the Federal Reserve Bank of Boston, or by the principals of the Board of Governors, or the Federal Reserve System.

This paper, which may be revised, is available on the web site of the Federal Reserve Bank of Boston at http://www.bostonfed.org/economic/wp/index.htm.

This version: July 14, 2016 


\section{INTRODUCTION}

Does private information about borrowers' credit quality prevail in interbank markets? In order to contain liquidity shortages and severe spillovers of money market tensions during the recent global financial crisis of 2007/08, major central banks intervened not only by injecting additional liquidity into the banking sector, but also by adjusting their monetary policy instruments in a way that made central banks "de facto the money market intermediary." 1 These interventions raise the general question of whether central banks (or other institutions) should assume the role of a central counterparty in the interbank market. A central bank acting as a central counterparty not only could eliminate contagion effects and market tensions that result from concerns about systemic risks, but also improve transparency and foster matching efficiency. The main argument usually put forward for a decentralized interbank market is that it ensures peer monitoring (e.g., Flannery 1996 and Rochet and Tirole 1996). Banks are expected to be better at gathering and processing information about their peer institutions. If this private information is reflected in interbank credit conditions, peer monitoring leads to a superior allocation of funds in the banking sector. A central bank acting as the main counterparty in the interbank market would not only lack this information, but the absence of peer monitoring would also seriously dampen (if not completely eliminate) banks' incentives to provide such private information and impede their ability to trade on it. Consequently, in order to assess the effects of central banks' intermediation in interbank markets during crisis periods and to evaluate whether a central counterparty in the money markets also would be beneficial in more tranquil periods, it is of utmost importance to have a precise assessment of the role that private information plays in the interbank market.

Gaining a good estimate of the importance of private information and relationship lending in the interbank market is also important from a regulatory perspective. If private information acquired through frequent transactions allows an interbank lender to better assess the credit risk of its counterparty, sound borrowers should obtain less costly funding from their interbank relationship lender than from other banks (if the former allocates some rent to the borrower). But this means

\footnotetext{
${ }^{1}$ Quoted from a speech by Benoît Coeuré, Member of the ECB's Executive Board, at the 15th Geneva Conference on the World Economy, "Exit Strategies: Time to Think About Them," Geneva, May 3, 2013. In these remarks, Coeuré explicitly argues that the ECB took several monetary policy measures that intentionally made it the intermediary for large parts of the euro money markets. In October 2008, the ECB moved to fixed-rate tenders with a full allotment in its repo operations, and matched this policy action by narrowing the "interest rate corridor", the difference between the rate on the marginal lending facility and the deposit facility, to 100 basis points (bps). Thus the "bid-ask-spread" with the ECB declined, which further reduced banks' incentives to take credit positions in the interbank market. In late 2008, the sum of funds deposited with and lent by the ECB through its standing facilities amounted to more than 115 percent of required reserves in the euro area, compared to less than 1 percent in the first half of 2008 . By that time, a major part of liquidity in the euro area interbank market was already channeled through the ECB's balance sheet. Similarly, in December 2007 the Federal Reserve adapted its operational framework and introduced, among other innovations, the term auction facility (TAF), which allowed all depository institutions to regularly receive direct credit from the central bank at the marginal bid rate determined in biweekly auctions. In addition, in late 2008 the Fed lowered the discount window's penalty lending rate and started paying interest on bank reserves.
} 
that if a relationship lender in the interbank market fails, this event also entails a loss of valuable private information and increases the funding costs to its former relationship borrowers, which might ultimately even lead to their failure. Consequently, if relationship lending prevails in interbank markets, financial contagion can spread in other ways besides borrowers defaulting on loans. The stability of interbank borrowers is also seriously endangered if a financial institution that serves as an interbank relationship lender fails. Therefore, whether a bank possesses private information about its peers and serves as an interbank relationship lender in the interbank market helps identify systemically important financial institutions (SIFIs). ${ }^{2}$

Despite its utmost relevance for monetary policy and financial stability, there is little empirical research on the role that private information plays in the interbank market, in particular due to scant transaction-level data on interbank lending. ${ }^{3}$ Our paper contributes to the literature by showing that relationship lending prevails in the interbank market. In particular, we provide empirical evidence that relationship lending matters for the availability and pricing of interbank liquidity because relationship lending reduces asymmetric information problems about counterparty credit risk. We base our analysis on transaction-level data of unsecured overnight lending between German banks that we derive from interbank payment records taken from the Deutsche Bundesbank's RTGSplus system, using an algorithm similar to Furfine (1999). We augment these data with banks' balance sheet information, banks' reserve holdings, banks' credit ratings, and other data to construct a daily panel of unsecured overnight loans between 1,079 distinct bank pairs granted from March 1, 2006, to November 15, 2007.

We use the interbank loan-level data to compute pairwise measures of lending and borrowing frequency, which serve as key proxies for relationship lending in the interbank market. We then estimate the effects of relationship lending on pairwise matching probabilities and bilaterally negotiated interest rates on interbank loans by using different sample selection models. To isolate the effects of relationship lending, we use a comprehensive set of time-varying bank and bank-pair control variables and saturate our specifications with a set of (time-varying) borrower, lender, and pair fixed effects. Our results show that relationship lending has an economically and statistically significant positive effect on the access to interbank liquidity. Relationship lending has a negative effect on the bilateral interest rate when market conditions suffer from credit risk uncertainty, even

\footnotetext{
${ }^{2}$ The notion that private information about counterparty credit risk is important in interbank markets and that it is difficult to replace a relationship lender in these markets must be the key reason why the Financial Stability Board assesses the systemic importance of a bank with respect to its connections in the interbank market on the asset side as well as on the liability side. See IMF/BIS/FSB "Report on Guidance to Assess the Systemic Importance of Financial Institutions, Markets and Instruments: Initial Considerations" (October 2009) (www.financialstabilityboard.org/ publications/r\_091107c.pdf) and the Basel Committee on Banking Supervision "Global Systemically Important Banks: Assessment Methodology and the Additional Loss Absorbency Requirement," Consultative Document, July 2011, p. 7, (www.bis.org/publ/bcbs201.pdf).

${ }^{3}$ See Cocco, Gomes, and Martins (2009), Ashcraft and Duffie (2007), and, more recently, Afonso, Kovner, and Schoar (2014).
} 
after controlling for time-varying borrower-, lender-, and pair-specific characteristics.

The primary objective of our analysis is to determine whether relationship lending mitigates uncertainty about counterparty credit risk in the money market. Therefore, we need to disentangle whether it is asymmetric information about counterparty risk that relationship lending helps to overcome, or whether only search frictions are mitigated by repeated interbank lending, as Ashcraft and Duffie (2007), among others, suggest. Separating these two effects is important: If indeed it is only private information about counterparty credit risk that makes relationship lending an important factor in allocating liquidity, then a decentralized interbank market can enhance market efficiency. If relationship lending only matters because it mitigates search costs in a decentralized market, then a centralized market directly eliminates these frictions and the benefits from relationship lending are less important.

Our dataset permits us to identify the effects that relationship lending has on reducing credit risk uncertainty in two ways. First, we derive an extensive set of control variables, in particular, time-varying pairwise measures of search frictions in order to separate the effect that established credit relations have on mitigating search costs. Second, we identify interbank credit decisions made during periods of severe counterparty credit risk uncertainty along two different dimensions, and study whether in these situations borrowers gain particular benefits from having established credit relationships.

Our first set of regressions uses the time dimension. In summer 2007, credit conditions in the unsecured money market shifted dramatically as problems with securitized subprime U.S. mortgages began to surface, an event that in retrospect marked the beginning of the global financial crisis of 2007/08. ${ }^{4}$ Since German banks were heavily invested in mortgage-backed securities via their conduits, the German banking sector was among the first and most severely affected by spillovers from the U.S. subprime crisis. ${ }^{5}$ On July 27, 2007, IKB Bank experienced a severe liquidity drain and as a consequence had to be rescued by a consortium comprised by-among others-Deutsche Bank, Commerzbank, and KfW, a government development bank. On August 17, 2007, the Association of German Savings Banks had to provide emergency liquidity assistance to Landesbank Sachsen (SachsenLB), which was taken over by Landesbank Baden-Württemberg (LBBW). ${ }^{6}$ From early August onwards, many other large banks dependent on wholesale funding, such as Westdeutsche

\footnotetext{
${ }^{4}$ Due to worries about counterparties' exposure to subprime mortgage risks, the credit risk spread in the 3-month money market (3M-Euriobor-OIS spread) jumped from basically zero in late July 2007 to 70 bps in early October 2007; see ECB (2013), p. 28 and Box 9. The defining moment in the summer of 2007 occurred on August 9, 2007, when BNP Paribas suspended withdrawals from three of its funds invested in U.S. mortgage-backed securities because, given the market turmoil, it was impossible to price these assets.

${ }^{5}$ To be precise, many German banks maintained conduits as off-balance-sheet entities that invested in structured financial products such as mortgage-backed securities and issued short-term papers. Banks granted their conduits extensive credit lines in order to mitigate roll-over risks. These credit lines exposed banks to the mortgage-backed securities held by their conduits when roll-over risks materialized in July and August 2007.

${ }^{6}$ More precisely, on August 26, 2007, the takeover was announced, and it became effective on January 1, 2008.
} 
Landesbank (WestLB), also reported severe difficulties in refinancing in the interbank market. ${ }^{7}$ Our dataset captures a period starting in summer 2007 that can effectively be regarded as a dress rehearsal for what took place on a larger scale in the later stages of the 2007/08 global financial crisis. We therefore study whether borrowers with established credit relationships had better access to interbank liquidity during this period of elevated credit risk uncertainty.

To further analyze whether relationship lending mitigates uncertainty about counterparty credit risk, we use a second set of regressions that exploits time-varying characteristics at the borrower level that are considered proxies for borrower opacity. For instance, we follow Morgan (2002) and use the level of disagreement between the major credit rating agencies about a bank's credit risk as measures of market participants' uncertainty about a borrower's true credit quality. As a further market-based proxy for uncertainty at the bank level, we use the recent volatility of a bank's credit default swap (CDS) spread. In addition, based on bank balance sheet information, we derive further proxies suggested by Morgan (2002) for measuring a bank's opacity, such as its ratio of loans to nonbanks relative to its total balance sheet size. Finally, we analyze if lending relationships are particularly important for bank pairs that are not part of the same formal interbank network arising from the structure of the German banking system. We use all these bank-specific variables to analyze whether these opaque borrowers benefit more from an established interbank lending relationship.

Our results suggest that search frictions indeed play a role in interbank markets and that bankpair relationships help to mitigate these frictions. However, we find that lending relationships are particularly important for overcoming information asymmetries about a borrower's credit quality. Controlling for the mitigating effect on search frictions, we find that borrowers benefit from established lending relationships, especially when credit decisions are impaired by elevated uncertainty about counterparty credit risk (lending during the crisis or lending to opaque borrowers). Borrower banks pay a significantly lower interest rate to their relationship lender as compared to arm's-length lenders, a result which suggests that borrowers benefit from a lower lemons premium. These findings are in line with theories of peer monitoring and relationship lending in corporate finance (see Boot 2000), which argue that proximity between a lender and borrower mitigates asymmetric information problems about the borrower's creditworthiness. Thus, our findings support the view that relationship lenders in the interbank market can better assess the credit quality of their closest borrowers and charge them lower interest rates than spot lenders.

\footnotetext{
${ }^{7}$ See, for example, Simensen and Atkins 2007 who argue that German banks were hit most severly by the subprime crisis and were among the first institutions to experience significant liquidity problems.
} 


\section{Related Literature}

Our paper draws on the large body of theoretical contributions about the implications of different informational frictions prevailing in the interbank market. Rochet and Tirole (1996), Freixas and Holthausen (2005), Freixas and Jorge (2008), and Heider, Hoerova, and Holthausen (2015) all model the implications that asymmetric information about borrower credit risk has on credit risk spreads and potential liquidity freezes in the unsecured interbank market. However, none of these theoretical papers studies how the repeated interactions between pairs of banks affect these informational asymmetries and what these relationships might imply about the pricing and availability of interbank credit. $^{8}$

We also draw on the vast literature on relationship lending between banks and nonfinancial firms. In this literature, it is well established that close ties between a bank and a borrowing firm influence the firm's access to finance in several possible ways (see Boot 2000 for a summary). For instance, Sharpe (1990), Rajan (1992), Petersen and Rajan (1995), and Hauswald and Marquez (2003) argue that repeated lending to the same borrower facilitates monitoring and screening for credit quality and thereby mitigates problems of asymmetric information about a borrower's creditworthiness - because subsequent monitoring of the same borrower is more efficient as it involves lower monitoring costs and/or improves the signal about the borrower's creditworthiness. ${ }^{9}$ As these models point out, credit market conditions strongly determine to what extent the advantage of having a relationship lender mitigates the borrowing firms' funding constraints. Related empirical work, such as Petersen and Rajan (1994) and Berger and Udell (1995), tries to quantify these implications by using the frequency of a lending relationship between a bank pair and the concentration in the borrower-lender relationship as proxies for the intensity of the lending relationship. ${ }^{10}$

Our paper is closely related to the empirical contributions of Furfine (1999), Cocco, Gomes,

\footnotetext{
${ }^{8}$ An exception is Babus (2011), who models how financial networks are formed when agents rely on costly relationships to access information about the transaction record of counterparties in order to decide on whether to trade risky assets over-the-counter. Similarly, Blasques, Bräuning, and van Lelyveld (2016) model the emergence of lending relationships in an interbank network due to search frictions and credit risk uncertainty.

${ }^{9}$ Interbank lending is commonly based on large volumes and unsecured loans. Thus, lending in this market involves taking large credit risks. In such a market, participants can extract information about their counterparties' credit risk through repeated interactions. An interbank lender can infer from a delayed or reneged repayment on an interbank loan that a particular borrower has a liquidity shortage (Babus 2011). In addition, banks may run costly checks on credit quality to gain private information on counterparty risk (see Broecker 1990). Intensive monitoring of all possible counterparties in the market, however, is costly, and banks may economize on these costs through repeated monitoring of the same set of borrowers, through which they can predict the default risk of their few borrowers (see Furfine 1999, and Craig and von Peter 2014).

${ }^{10}$ Petersen and Rajan (1994) and Degryse and Ongena (2005), for instance, also use measures of geographical proximity between a lender and borrower as a proxy for private information. But Petersen and Rajan (2002) show that for the United States, even when lending to small- and medium-size firms, distance became less relevant for the credit relationship as information and communication technologies improved. Thus, we do not explicitly consider local proximity between banks in Germany as an important determinant of interbank relationships and informational advantages in the interbank market.
} 
and Martins (2009), Affinito (2012), Afonso, Kovner, and Schoar (2014), and Craig, Fecht, and Tümer-Alkan (2015), all of which study relationship lending in the interbank market. While Furfine (1999) shows that relationship lending indeed prevails in the U.S. interbank market, Cocco, Gomes, and Martins (2009) find that banks in the Portuguese market use relationships to insure against liquidity shocks. However, Cocco, Gomes, and Martins (2009) do not try to disentangle whether established relationships matter because they mitigate search costs or because they reduce informational asymmetries about counterparty risks. Using more recent data on the Italian interbank market, Affinito (2012) shows that interbank relationships also persist over time, and functioned well during the recent crisis. But since Affinito does not have data on the actual interest rate charged, he cannot study how bilateral lending relationships affect the cost of credit.

Most closely related to our paper is the empirical work by Afonso, Kovner, and Schoar (2014) and Craig, Fecht, and Tümer-Alkan (2015). Afonso, Kovner, and Schoar (2014) also use bilateral interbank transaction data to study the role of relationships in mitigating search frictions and informational asymmetries. However, in contrast to their dataset, our payments data exclude repo transactions and allow us to identify the banks ultimately lending and borrowing in the interbank market and distinguish them from financial institutions that only serve as an intermediary in the processing of payments. ${ }^{11}$ Craig, Fecht, and Tümer-Alkan (2015) find that relationship lending in the German interbank market affects banks' bidding behavior in the ECB's open market operations. They derive interbank relationships from credit register data that also contain long-term interbank loans, but do not contain information on the pricing of these loans. However, their data do not permit them to disentangle whether these relationships matter by mitigating search costs or by helping to overcome informational asymmetries about counterparty credit risk.

Another more recent theoretical contribution by Duffie, Garleanu, and Pedersen (2005) stresses the role of search frictions in over-the-counter (OTC) markets, such as the unsecured interbank market. Ashcraft and Duffie (2007) apply these ideas to the U.S. federal funds market and study to what extent banks repeatedly interact with the same counterparties to insure against liquidity risk in the presence of search frictions. If a particular bank can always interact with the same counterparty to smooth out liquidity shocks, it avoids costly counterparty search in a decentralized market and relies on the relationship as its insurance mechanism. This argument is also found in Cocco, Gomes, and Martins (2009) and Afonso, Kovner, and Schoar (2011); each study finds that borrowers with larger liquidity shocks rely more on lending relationships to access liquidity. Bech and Klee (2011) provide evidence that in the OTC structure, the surplus generated by the match between the borrower and the lender is indeed split relatively equally among the two.

\footnotetext{
${ }^{11}$ Maybe due to these differences in the quality of the underlying data, our key results also differ from their findings: Our results show that relationships matter not only because they reduce search costs in the interbank market. In addition, we find that relationships also play an important role in mitigating informational asymmetries about counterparty credit risk in the interbank market.
} 
The remainder of the paper is structured as follows. Section 2 describes the panel dataset on which we base our empirical analysis. Section 3 describes the empirical strategy and our econometric model. In Section 4, we discuss the results and Section 5 concludes. The appendix contains institutional background on interbank liquidity and the most important features of the German banking system and details on the data, as well as all figures and tables.

\section{Data AND Descriptive Analysis}

We analyze the role of interbank relationship lending using data from the German interbank lending market. The German banking sector, the largest in the euro area and one of the earliest to suffer from the crisis that began in 2007, provides a unique platform to study the effects of interbank relationships (for institutional details of the German banking system and interbank liquidity, see Appendix A). In our main analysis, we focus on the effects of interbank relationships on the extensive margin of credit (access to liquidity) and the intensive margin of credit (price of liquidity). In particular, we model the probability that a loan is granted between lending bank $i$ and borrowing bank $j$ at day $t$ (matching probability), as well as the bilateral interest rate spread of granted loans Spread $_{i, j, t}$, defined as the difference between the loan's interest rate and the ECB target rate. To derive data on bilateral interbank loans, we use interbank payment data from the German segment of the European interbank payment system, TARGET (RTGSplus), from which we obtain a panel of overnight interbank loans at daily frequency from March 1, 2006, through November 15, 2007, using an algorithm similar to Furfine (1999). ${ }^{12}$ Appendix B provides a detailed discussion of the implementation of the algorithm.

We match the loan-level overnight interbank lending data with information from other sources. First, we use monthly balance sheet data for individual banks. The monthly balance sheet statistics are obtained from the Deutsche Bundesbank and contain an analytically important breakdown of the balance sheet items by type, term, debtor, and borrower sector for each German bank. Second, we make use of individual banks' daily reserve information, also obtained from the Deutsche Bundesbank. These data list each institution's end-of-business-day reserve holdings as well as the institution's reserve requirement. Similar to the balance sheet data, individual banks' reserve holdings are confidential and not publicly available. Moreover, we use credit default swap (CDS) spreads of German banks which we collect from the Depository Trust and Clearing Corporation and issuer ratings from Bloomberg. Other data, such as data on monetary policy actions like changes in target rates and open market operations, are collected from the ECB homepage. Our final dataset covers the period from March 1, 2006, until November 15, 2007, and contains loans between 1,079 bank

\footnotetext{
${ }^{12}$ On November 19, 2007, TARGET2, a fully integrated pan-European real time gross settlement system, replaced TARGET, which only linked the national real time gross settlement systems of the EMU member states.
} 
pairs involving 77 different banks. ${ }^{13}$

Figure 1 depicts the ECB target rate, the Euro OverNight Index Average (EONIA) rate, and the daily volume-weighted average interest rate computed from our data. On most days, the EONIA rate is some basis points above the central bank's target rate, and the average daily interest rate from our data is close to, but slightly above, EONIA. It is also striking that the volatility of the two average rates apparently increased after the financial crisis began on August 9, 2007, indicated by the solid vertical line (in red). Figure 2 shows that on most days, the number of lending banks (lenders) exceeds the number of borrowing banks (borrowers), implying that on average lender banks lend smaller amounts, whereas their counterparties seek to borrow larger amounts. A visual inspection also reveals that the recurrent peaks of both series coincide with the last day of the maintenance period indicated by vertical dashed lines (in gray). The same holds true for the total amount lent per day and the total number of loans per day (Figure 3). Thus interbank market activity is typically higher at the end of the maintenance period.

The plots also suggest different time-series behaviors before and during the financial crisis. Therefore, we use a t-test to check for a mean shift in these time series after the crisis began on August 9, 2007. For most series, we find significantly different means before and during the crisis (see Table 1). In particular, the mean rate decreased and market activity increased, while the cross-sectional variation (standard deviation) of interest rates at which different bank pairs agreed on during the same day was three times higher during the crisis period. ${ }^{14}$ Hence, during the first stage of the financial crisis, banks continued to lend overnight funds and interbank market activity increased in this very short-term segment of the money market (for similar evidence, see Afonso, Kovner, and Schoar 2011, and Heijmans, Heuver, and Walraven 2011). Nevertheless, the increased interest rate volatility in both cross-section and time dimensions clearly testifies to the market turbulence related to the crisis. Moreover, during the financial crisis, the German interbank market became significantly tighter for borrowers.

To better understand the general lending patterns in the German overnight interbank market, Table 2 depicts the number of borrowers and lenders, how often each bank borrowed or lent, as well as the respective amounts for banks of different asset sizes. In general, our data reveal that, similar to findings by Craig and von Peter (2014), the German overnight interbank market exhibits

\footnotetext{
${ }^{13}$ We focus on banks for which balance sheet data and reserve holdings are available. We also excluded banks that participated less than 50 times in the interbank market and pairs that had no transactions during the entire sample.

${ }^{14}$ The average daily transaction volume (in numbers and amounts), as well as the average loan size, was significantly higher during the crisis, while the mean spread was significantly lower. These conditions reflect the maturity shortening - a symptom of banks' precautionary liquidity hoarding — that made it difficult even for high-quality borrowers with excellent credit to obtain funding at longer maturities. These conditions forced those banks into borrowing primarily in the overnight segment and exposed them to an elevated roll-over risk. See Acharya and Skeie (2011) for a formal analysis of this effect and Abbassi, Bräuning, Fecht, and Peydró (2015) for empirical evidence on this effect in the euro area.
} 
a core-periphery structure. ${ }^{15}$ In particular, large banks (with more than EUR 100 billions asset size) have on average 34 different lenders, and borrow and lend larger amounts than banks in other asset-size classes. Moreover, about 13 percent of the 1,079 bank pairs in our sample are formed by a borrower and a lender that each have assets over EUR 100 billion. Almost 70 percent of all bank pairs are formed by two banks that have more than EUR 10 billion in assets. These large and highly interconnected core banks act as money center banks that are at the core of the overnight lending network. Moreover, Table 2 shows that small banks (with less than EUR 1 billion asset size) are on average net lenders and have on average only 1.5 lenders (versus 6.5 borrowers), confirming the results of Furfine (1999) and Cocco, Gomes, and Martins (2009) for the German market. ${ }^{16}$

\section{VARIABles AND Empirical ApProach}

In this section, we define the variables that we use in the analysis and discuss the empirical strategy used to identify the effects of relationship lending on interbank liquidity. In particular, we discuss how we identify the effects of lending relationships on reducing asymmetric information about credit risk as compared to with effects that bank-pair relationships have on mitigating search frictions.

\subsection{INTERBANK RELATIONSHIP VARIABLES}

According to Boot (2000), the definition of relationship banking in the bank-firm context centers around two issues, proprietary information and multiple interactions, underscroring that close ties between a lender bank and its borrower might facilitate monitoring and screening, which can mitigate problems of asymmetric information about the borrower's creditworthiness. Petersen and Rajan (1994) note that the strength of a relationship between a firm and a bank can be measured by the frequency of interactions, through interactions over multiple products, or by the concentration of a firm's borrowing with one creditor. We employ a similar logic with respect to bank pairs.

Therefore, as the first measure of relationship lending, we use the frequency of interactions between any two banks in the overnight market (see also Furfine 1999). More precisely, we compute the logarithm of one plus the number of days a bank $i$ has lent to bank $j$ over a certain time period

\footnotetext{
${ }^{15}$ This tiering structure is a common feature of interbank markets that has been found using different measures for many developed economies. Bech and Atalay (2010) find evidence for it in the U.S. federal funds market. Similarly, Wetherilt, Zimmerman, and Soramaki (2010) also show that the U.K. sterling overnight interbank market exhibits a core of highly connected banks alongside peripheral banks.

${ }^{16}$ Small retail banks are typically net lenders in the U.S. interbank market, either because such banks are deposit collectors or because there is little public information available about the creditworthiness of small banks, thus limiting the number of banks willing to lend. As a consequence, these small banks manage their reserves in a way that they are net lenders (see Ho and Saunders 1985).
} 
$T$ as

$$
R L_{i, j, t}=\log \left(1+\sum_{t^{\prime} \in T} I\left(y_{i, j, t^{\prime}}>0\right)\right),
$$

where $I(\cdot)$ is the indicator function, and $y_{i, j, t}$ denotes the amount bank $i$ lends to bank $j$ at time $t$. This variable captures how often a lender received a signal about the borrower and how often this pair successfully transacted a loan. We compute the relationship variables over a 30-day period such that $T=\{t-1, . . t-30\}$. The length of the rolling window was proposed in Furfine (1999), but we also test longer periods to check robustness. In line with Petersen and Rajan (1994), the frequency-based relationship variable is a proxy for private information due to the lender's past experience with the borrower. We also consider the potentially two-sided nature of interbank relationships and compute the reciprocal relationship variable, defined as Reciprocal_ $R L_{i, j, t}=R L_{j, i, t}$, to account for possible mutual insurance against liquidity shocks.

Our baseline relationship measures rely on the frequency of interactions but do not take into account the depth of the bilateral relationship, meaning the amount lent, relative to other counterparties. To check the robustness of our main results, we therefore construct alternative relationship measures that are normalized by total trading volume. Similar to Cocco, Gomes, and Martins (2009), we compute the amount $y_{i, j, t^{\prime}}$ lender $i$ grants to borrower $j$ at time $t^{\prime}$, summed over a certain time period $T$ relative to the overall amount lent by bank $i$ over the same period $T$. Formally, the lender-preference index $(L P I)$ is defined as

$$
L P I_{i, j, t}=\frac{\sum_{t^{\prime} \in T} y_{i, j, t^{\prime}}}{\sum_{j} \sum_{t^{\prime} \in T} y_{i, j, t^{\prime}}} .
$$

We set the LPI to zero if the denominator is zero, meaning if bank $i$ did not lend at all to borrower $j$ during the reference period $T$. Because interbank relationships are persistent but not immutable over time, we also compute these relationship variables over the previous 30-day period, i.e. $T=\{t-1, . . t-30\}$.

Analogously, we compute the borrower-preference index $(B P I)$ as the amount bank $j$ borrowed from bank $i$ at time $t^{\prime}, y_{i, j, t^{\prime}}$, summed over a certain time period $T$ relative to the overall amount borrowed by bank $j$,

$$
B P I_{i, j, t}=\frac{\sum_{t^{\prime} \in T} y_{i, j, t^{\prime}}}{\sum_{i} \sum_{t^{\prime} \in T} y_{i, j, t^{\prime}}} .
$$

Again, we compute the BPI based on the last 30 days, i.e., $T=\{t-1, . . t-30\}$. Both variables, LPI and BPI, are negatively correlated with the number of different counterparties and asset size. When applying these measures, we call a bank with a high $L P I$ a relationship lender, and a bank with a high $B P I$ a relationship borrower. ${ }^{17}$

\footnotetext{
${ }^{17}$ Most of the relationship lending literature has focused on the frequency of interaction $(R L)$ or on concentration measures $(L P I / B P I)$ as proxies for the strength of the lending relationship. The frequency of a lending relationship
} 
Table 3 reports the correlations between our alternative relationship measures. As the results indicate, the measures succeed in capturing different aspects of interbank lending relationships. The frequency of an interaction between two banks $\left(\mathrm{RL}_{i, j, t}\right)$ and the concentration of the lending bank's interbank credit portfolio on the respective borrower $\left(\mathrm{LPI}_{i, j, t}\right)$ are highly related, with a correlation of 0.69 . However, with a correlation of 0.48 , the frequency of an interaction is less correlated with the borrowing concentration measure $\left(\mathrm{BPI}_{i, j, t}\right)$. In turn, $\mathrm{LPI}_{i, j, t}$ and $\mathrm{BPI}_{i, j, t}$ have a correlation of 0.31 , while $\mathrm{RL}_{i, j, t}$ and Reciprocal_ $\mathrm{RL}_{i, j, t}$ have a low correlation of 0.05 .

\subsection{ECONOMETRIC MODEL}

We use a regression-based approach to investigate the effect of bank-pair relationships on the availability and pricing of interbank liquidity. Because participation in the interbank market is endogenous and we only observe the bilateral interest rate when a match is successful, i.e., a loan is granted, we need to account for the possibility of sample selection on unobservables, a situtation that may lead to inconsistent parameter estimates. Therefore, similar to Heckman (1979), we use a bivariate sample selection model that comprises the outcome equation for the bilateral interest rate spread (to the target rate) between lender $i$ and borrower $j$ at day $t$ :

$$
\operatorname{Spread}_{i, j, t}= \begin{cases}r_{i, j, t}^{*} & \text { if } \operatorname{Loan}_{i, j, t}=1 \\ - & \text { if } \operatorname{Loan}_{i, j, t}=0\end{cases}
$$

and the selection equation for $\operatorname{Loan}_{i, j, t}$ that indicates an interbank loan between lender $i$ and borrower $j$ at day $t$ :

$$
\operatorname{Loan}_{i, j, t}= \begin{cases}1 & \text { if } y_{i, j, t}^{*}>0 \\ 0 & \text { if } y_{i, j, t}^{*} \leq 0\end{cases}
$$

The observed variables $\operatorname{Spread}_{i, j, t}$ and $\operatorname{Loan}_{i, j, t}$ are linked to the latent variables $y_{i, j, t}^{*}$ and $r_{i, j, t}^{*}$, which are modeled by the linear equations,

$$
\begin{aligned}
& r_{i, j, t}^{*}=w_{i, j, t}^{\prime} \beta+F E s+u_{i, j, t} \\
& y_{i, j, t}^{*}=w_{i, j, t}^{*^{\prime}} \beta^{*}+F E s+u_{i, j, t}^{*},
\end{aligned}
$$

allows us to assess the potential informational advantage that a particular lender has over other market participants due to information that the bank received through the repeated interactions. The BPI measures a borrower's dependency on a particular lender, and provides an indication of the lender's market power over the borrower and the lender's ability to extract a rent from the bank-pair relationship. If a bank has a high lending concentration $(L P I)$, the lending bank has a relatively concentrated credit risk exposure in the unsecured lending market. Banks with such a lending structure economize on the costs of monitoring and should have stronger incentives to intensely monitor their small number of (relationship) borrowers. Therefore, high-LPI banks should, everything else equal, have superior information about the creditworthiness of their closest borrower banks compared to spot lenders. This argument is in line with the theoretical findings of Nieuwerburgh and Veldkamp (2010). 
where $w_{i, j, t}$ and $w_{i, j, t}^{*}$ are vectors of independent variables, and $F E s$ denotes different sets of fixed effects depending on the precise model specification. We assume the error terms $\left(u_{i, j, t}^{*}, u_{i, j, t}\right)$ follow a bivariate normal distribution with variances $\sigma_{u^{*}}^{2}=1=\sigma_{u}^{2}$ and correlation $\rho$. If $\rho \neq 0$, the OLS estimator for the outcome model is generally biased. To correct for this selection bias, we use the Heckman two-stage procedure that leads to a consistent estimator of the second-stage parameters. Therefore, we first estimate a standard Probit model for $L o a n_{i, j, t}$, given by Equations (5) and (7); then correct for possible selection bias by including the inverse Mills ratio in the interest rate equations that we then estimate by OLS. ${ }^{18}$ We cluster robust standard errors at the borrower level. ${ }^{19}$

Our analysis is specifically focused on disentangling the role that bilateral lending relationships play in mitigating search frictions and in overcoming informational asymmetries related to credit risk. We therefore control for other factors that affect interbank lending (such as bank size, credit risk and search frictions) by including both bank-pair, bank-level, and time-level control variables. Moreover, we include a large set of fixed effects to isolate the bank-to-bank variation in credit availability and interest rates. In particular, for all specifications, we include daily time fixed effects to control for aggregate changes in liquidity, and borrower and lender fixed effects to control for bank characteristics that might affect market participation and the pricing of loans. To further isolate the effects of bilateral lending relationships on interbank liquidity, we pursue two sets of analysis.

In our first set of analyses, we use the time dimension of the data and include in our models the interaction terms of our relationship variables with proxies for both periods of high credit risk uncertainty and search frictions. In order to separate these two channels, we therefore specify $w_{i, j, t}^{\prime} \beta$ (and analogously $w_{i, j, t *}^{*^{\prime}} \beta^{*}$ ) as

$$
w_{i, j, t}^{\prime} \beta=\beta_{1} \cdot \operatorname{Rel}_{i, j, t}+\beta_{2} \cdot \operatorname{Rel}_{i, j, t} \times \text { Crisis }_{t}+\beta_{3} \cdot \operatorname{Rel}_{i, j, t} \times \text { Search Frictions }_{t}+x_{i, j, t}^{\prime} \beta_{x},
$$

where $x_{i, j, t}$ is a vector of control variables, and the variable $\operatorname{Re}_{i, j, t}$ generically denotes the relationship variable $\left(R L_{i, j, t}, L P I_{i, j, t}\right.$, or $\left.B P I_{i, j, t}\right)$. The second term interacts the variable $R e l_{i, j, t}$ with the dummy variable $\mathrm{Crisis}_{t}$ that indicates the crisis period beginning on August 9, 2007. ${ }^{20}$ During the crisis period, uncertainty about counterparty credit risk increased dramatically, particularly in the German interbank market. ${ }^{21}$ Thus, private information about counterparty risk became more important for

\footnotetext{
${ }^{18}$ The two-step approach hinges on a valid exclusion restriction: the selection equation must comprise at least one variable that only affects the matching of a pair, but not the interest rate for the loan. We use the excess reserves of the lender (Excess_reserves $\left.{ }_{i, t}\right)$ and the borrower (Excess_reserves ${ }_{j, t}$ ) as the exclusion restriction. Both variables have a significant impact on market participation but do not significantly affect the pricing of credit; hence these are valid exclusion restrictions.

${ }^{19}$ Our main result continues to hold if we cluster at the borrower-day or borrower-lender pair level.

${ }^{20}$ In retrospect, August 9, 2007, was widely recognized as the start of the 2007/08 global financial crisis. On this day, BNP Paribas suspended withdrawals from three of its hedge funds invested in subprime mortgage-backed securities due to the inability to price these assets in the market.

${ }^{21}$ This is suggested, for instance, by the huge increase in the cross-sectional standard deviation of borrowing rates within a given day after August 9, 2007 (see Table 1). Flannery, Kwan, and Nimalendran (2013) provide further
} 
the allocation and pricing of liquidity. Consequently, if the first interaction term has a positive effect on the matching probability in Equation (7) and a negative effect on the interest spread in Equation (6), these results would be further indications that relationship lending indeed mitigates uncertainty about counterparty risk.

The third term interacts the relationship variables with proxies for search frictions in order to disentangle the effect that relationship lending may have on mitigating problems associated with costly counterparty search. As a proxy for search frictions, we use the concept of market tightness, computed as the number of lenders divided by the number of borrowers (Market_tight $t_{t}$ ) participating in the interbank market on a given day. This measure has been extensively used in the search literature to characterize search frictions in decentralized markets (see Bech and Monnet 2016). Our analysis uses the dummy variable Tightness, which equals one if the day is in the lowest quantile of the distribution of the Market_tight $t_{t}$, and is zero otherwise. Hence, on days of high market tightness, there are very few lenders willing to extend loans. As a further measure of search frictions, we use the total number of daily transactions (Total_trans $s_{t}$ ) and analogously construct the dummy variable Total_trans_d $d_{t}$. During these days, it is more difficult to find a new counterparty. Hence, the search cost for borrowers is high, and banks may rely on their established relationships in the overnight market to a larger extent. Therefore, this interaction term further controls for the time-varying effects that established bank-pair relationships have on mitigating search costs (the search costs not related to credit risk uncertainty). ${ }^{22}$

In our second set of analyses, we more closely investigate the effect of bank-pair relationships on mitigating asymmetric information problems by checking how our relationship variable interacts with proxies of time-varying borrower opacity. ${ }^{23}$ Therefore, we specify $w_{i, j, t}^{\prime} \beta$ (and analogously $w_{i, j, t *}^{*^{\prime}} \beta^{*}$ ) as

$$
w_{i, j, t}^{\prime} \beta=\beta_{1} \cdot \operatorname{Rel}_{i, j, t}+\beta_{4} \cdot \operatorname{Rel}_{i, j, t} \times \text { Borrower Opacity }_{j, t}+x_{i, j, t}^{\prime} \beta_{x}
$$

where $x_{i, j, t}$ includes the same control variables as in Equation (8). We use several proxies of borrower opacity that indicate particularly severe asymmetric information problems at the borrower level. First, we use the measure of a bank's CDS-spread variability to proxy for uncertainty about borrower risk. Specifically, we use the coefficient of variation of the five-year CDS spread, computed based on

empirical evidence that bank opacity indeed dramatically increased during the crisis.

${ }^{22}$ Obviously, one may also expect that search frictions play a different role during a crisis and that established interbank credit relations have a more substantial impact on mitigating them. We take this into account by allowing for a different effect of our search friction controls (the correlation of liquidity shocks and the bilateral surplus of the lender and the borrower) as well as how market tightness interacts with our relationship measure during a crisis, i.e., we also interact those explanatory variables with the crisis dummy.

${ }^{23}$ We have also interacted all borrower opacity variables with the crisis dummy and included search frictions proxies. While our results are similar if we include interactions with relationship variables, borrower opacity, and aggregate market conditions, we choose to separate them to facilitate the presentation of results. 
a 30-day rolling window period. A higher variability in the CDS spread provides a market-based measure of the uncertainty related to the assessment of the borrower bank's credit risk. Second, we follow Morgan (2002) and use the disagreement among credit rating agencies as a proxy for opacity. From Bloomberg, we obtain issuer ratings from the three major rating agencies-Moody's, Standard and Poor's, and Fitch Ratings - and compute a measure of disagreement among these three agencies about the solvency of a given bank. According to the procedure outlined in Jewell and Livingston (1999), we transform the different rating scales to a homogeneous numerical scale which enables cross-comparisons. We then compute the standard deviation of ratings for a given bank, and define a dummy variable (Split_rating $g_{j, t}$ ) that equals one whenever the standard deviation is positive, meaning the three rating agencies disagree about the bank's credit quality, and is zero otherwise. We use this measure of disagreement as a further proxy for bank-level credit risk uncertainty.

Moreover, we use five balance sheet variables as proxies for bank opacity. First, following Afonso, Kovner, and Schoar (2014), for a borrower in the interbank market we use the ratio of loans to nonbanks relative to total assets $\left(\right.$ Loans $\left._{j, t}\right)$ on the bank's balance sheet as a proxy for its opacity. ${ }^{24}$ Since the value of loans is especially hard to assess for third parties, borrowers with a relatively high loan-to-asset ratio suffer from a particularly severe informational asymmetry about their credit risk. Second, following Morgan (2002), we also use the share of tradable assets (securities) as a further opacity measure, since the position of this asset class can be changed rapidly without outsiders taking notice. Third, we define the variable Securities $_{j, t}$ as the fraction of securities relative to total assets. Fourth, in accordance with Morgan (2002), we use the variable Cash $_{j, t}$ as the fraction of cash holdings to total assets, since cash is the most liquid asset. Fifth, we also use the debt-to-total-asset ratio, $D_{e b t}{ }_{j, t}$, as a simple measure of a bank's leverage.

Finally, asymmetric information problems between a lender and borrower might be more severe if the two banks do not belong to a formal network that arises from the German banking system's structure. As discussed in the Appendix, two main pillars of the German banking system are the public and the cooperative banking sectors. Both have head institutions that provide the retail banks with access to wholesale markets, and this arrangement constitutes a network with formal interbank relationships. Fecht, Nyborg, and Rocholl (2011) show that belonging to either of these two formal networks matters for the pricing and availability of liquidity to banks. Therefore, at the bank-pair level, we construct a dummy variable (No_formal_networ $\left.k_{i, j}\right)$ that equals one if lending bank $i$ and borrowing bank $j$ do not belong to the same formal network, and is zero otherwise.

\footnotetext{
${ }^{24}$ We enter all balance sheet variables in the analysis according to the last balance sheet statement preceding day $t$ to ensure the values are pre-determined.
} 


\subsection{CONTROL VARIABles}

To isolate the effects of relationship lending on mitigating asymmetric information problems, we include borrower, lender, and day fixed effects in all our baseline models. We also estimate the interest rate models with time-varying borrower fixed effects at a monthly frequency to account for changes in observed and unobserved borrower characteristics; for instance, credit risk or lack of demand for credit. ${ }^{25}$ Moreover, in our analysis we control for other time-varying borrower, time-varying lender, and time-varying bank-pair characteristics by including the vector of control variables, $x_{i, j, t}$, that may affect bilateral interbank lending and the associated interest rate if a loan is granted.

For the decision to participate in the loan and the pricing of loans, a bank's size measured by the logarithm of total assets is an important factor $\left(\right.$ Asset $\left._{i, t}\right)$; our descriptive analysis and Furfine (2001) show that bank size is a key factor of market participation. From the perspective of a borrower bank, larger banks seem to be more creditworthy due to better available information (frequency, public reporting, media coverage, and so on) or because they might be subject to too-big-to-fail policies. Large banks also may be able to make profitable investments in overnight loans because they can better refinance themselves (see Ashcraft and Duffie 2007).

Similarly, lender and borrower banks that are more active and connected in the interbank market might obtain better rates. For this purpose, we compute the Bonacich centrality during the last 30 days (Centrality, ) , a network measure that captures the importance of a certain node in the network. A high centrality measure indicates that a bank is more connected, particularly to more connected counterparts. Thus, this measure captures the extent to which a bank has established other lending relationships, especially with banks that themselves dispose of a wide network of relationships (for an application to interbank markets, see Bech and Atalay (2010)).

Moreover, we use the equity ratio $\left(E_{\text {quity }}, t\right)$, since better capitalized banks can withstand larger losses. Thus, their outstanding debt carries a lower default risk, which allows them to borrow at lower rates. ${ }^{26}$ Moreover, since banks might not be able to precisely assess the credit risk of their counterparties, banks with higher equity ratios may be more likely to obtain credit.

A key driver of banks' participation in the interbank market is the need to fulfill reserve requirements. A low ratio of actual reserves being held relative to reserve requirements should increase the probability that a bank borrows funds in the interbank market. We follow Fecht, Nyborg, and Rocholl (2011) and define Excess_reserves ${ }_{i, t}$ as the difference between a bank's actual reserve holdings on a given day and the reserves the bank needs to hold on a daily basis to fulfill its reserve

\footnotetext{
${ }^{25}$ For computational reasons, we do not estimate such a large set of fixed effects for the binary matching models. We include them only in the models for the bilateral interest rate that are at the core of our analysis.

${ }^{26}$ Furfine (2001) has documented a significant effect of a bank's equity ratio on the interest rates it pays in the federal funds market.
} 
requirement until the end of the maintenance period. In order to account for the fact that a bank can better smooth negative excess reserves if there are more days left in a given maintenance period, excess reserves are normalized by the number of days left in the maintenance period. ${ }^{27}$

Previous studies have found that liquidity risk affects interbank market participation and the pricing of interbank loans (Cocco, Gomes, and Martins 2009). If a bank is exposed to relatively large liquidity shocks, it might need to trade funds at unfavorable prices. We proxy for liquidity risk using the standard deviation of the daily change in a bank's reserve holdings over a 30-day rolling window, normalized by the bank's reserve requirements $\left(L i q \_r i s k_{i, t}\right)$.

Moreover, we control for the effect that established relationships have on mitigating search frictions. Therefore, we construct several variables at the bank-pair level that capture the efficiency a bank gains from approaching the same lender again rather than searching for a new counterparty. As a first measure, we compute the correlation of liquidity shocks $\left(C o r r \_l i q \_s h o c k s s_{i, j, t}\right)$, proxied by the daily change in reserve holdings, between two banks over the last month. A high negative correlation implies that two banks, a lender and a borrower, are likely to be on opposite sides of the market; hence, they may benefit more from risk sharing and should therefore be more likely to form a lending relationship (for a theoretical model of this argument, see Fecht, Grüner, and Hartmann 2012). But more importantly, if a bank learned through past lending relationships that a particular counterparty has negatively correlated liquidity shocks, it may approach this particular counterparty again when searching for funds. Therefore, including the correlation of liquidity shocks ensures that the observed effects of lending relationships on the availability and pricing of interbank loans are not driven by the fact that some bank pairs are more likely to trade because of complementary liquidity shocks.

Second, we also expect that banks will choose to stick with a previous counterparty based on the rates they paid to this counterparty relative to other market participants. The decision to invest in further search efforts for new counterparties depends on how profitable deals with a particular counterparty were in the past. Thus, the matching probability between lending bank $i$ and borrowing bank $j$ should depend positively on the previous surplus banks $i$ and $j$ realized when trading with each other in the past, compared to the other available bargaining options. To measure the realized surplus from a lending relationship, we derive the average rate a lender obtained on loans over the past 30 days: $\bar{r}_{i, t}^{l e n}=\frac{1}{N} \frac{1}{T} \sum_{j} \sum_{t^{\prime} \in T} r_{i, j, t^{\prime}}=\frac{1}{N} \sum_{j} \bar{r}_{i, j, t}$, with $\bar{r}_{i, j, t}=\sum_{t^{\prime} \in T} r_{i, j, t^{\prime}}$ and $T=\{t-1, \ldots, t-30\}$. Then we compute the past realized surplus for lender $i$ as Lender_surplus $s_{i, j, t}=\bar{r}_{i, j, t}-\bar{r}_{i, t}^{l e n}$ and, analogously, for the surplus of borrower $j$, Borrower_surplus $s_{i, j, t}=\bar{r}_{j, t}^{b o r}-\bar{r}_{i, j, t}{ }^{28}$ The surplus

\footnotetext{
${ }^{27}$ Throughout the paper, whenever necessary, we include lagged variables to ensure that all right-hand-side variables are predetermined. For instance, for each bank at day $t$, we include the lagged excess reserves at the end of the previous business day, $t-1$. Similarly, we use balance sheet data based on the last month; see the definitions of variables.

${ }^{28}$ We normalize each bank's surplus with respect to the minimal surplus, and we set the realized surplus equal to
} 
variables serves as a proxy for the true surplus relative to the unobserved outside options for banks $i$ and $j$, respectively. ${ }^{29}$

In Table 8, we present summary statistics, and, in Table 9, we show the definitions of all variables used in the analysis.

\section{Estimation Results}

In this section, we discuss the estimation results from our selection models for the bilateral matching probability and interest rates of granted loans that were described in Section 3.2. We first discuss the results on interbank relationship lending and aggregate market conditions, then analyze the interaction between relationship lending and borrower opacity.

\subsection{Relationship Lending and Aggregate Market Conditions}

Table 4, Models (1)-(5), presents the estimation results of the bilateral matching models. Models (6)-(11) present the second-stage estimates for the bilateral interest rate models for the pricing of granted loans. In all the matching models, we include lender, borrower, and day fixed effects as well as time-varying borrower and lender characteristics. ${ }^{30}$ We find that the estimated coefficient of the relationship variable is positive and highly significant. This result indicates that banks rely on repeated interactions with specific counterparties, as shown in Model (1). Hence, bank-pair relationships in the interbank market are persistent, and the formation of these relationships is not random but depends on the past bilateral lending frequency. Moreover, banks that are not in a formal network are significantly less likely to grant a loan to each other. Since the reverse relationship measure has a positive and significant coefficient, this result provides support for the view that banks mutually provide liquidity to each other.

Model (2) presents the specification when we also include the interaction term of the relationship variables and the crisis dummy to assess whether bank-pair relationships were more important during periods when uncertainty about counterparty credit risk was presumably elevated. The coefficient of the first interaction term $(R L \times C r i s i s)$ is, however, not significantly different from zero. Thus, we do not find evidence that during the crisis period lenders were more likely to lend

zero if bank $i$ and $j$ did not trade during the last 30 days.

${ }^{29}$ Note that this variable captures the incentives of the borrower and lender to stick to a lending relationship rather than searching for new counterparties and might also reflect some informational asymmetries about counterparty risk. If a particular lender offers a better deal to a borrower compared to other market participants, this might simply result from this bank's ability to make a more precise credit risk assessment of the borrower. However, including this control variable ensures that the remaining effect of established relationships on interbank lending is not driven by search cost considerations, but rather reflects private information on counterparty credit risks obtained through lending relationships.

${ }^{30}$ The estimated coefficients of these variables are omitted from the table to avoid clutter. 
to frequent borrowers. So the elevated uncertainty about banks' credit risk during the 2007 crisis did not significantly induce banks to restrict their lending to those counterparties with whom they most frequently interacted when economic conditions were more normal. However, during the crisis, frequent past interaction increases the probability of agreeing on a new loan.

Next, we control for search frictions and gauge the extent to which frequent interactions mitigate these frictions. In Model (3), as a further control variable we include the interaction between the market tightness and the frequency of bank-pair interactions. This step tests the idea that established relationships with a lender bank might be particularly important on days when few lenders face many borrowers. Having borrowed from a lender frequently in the past does not significantly affect the probability of receiving a new loan from this lender if the market is tight, i.e., search frictions are high. This relationship also does not change if we allow for a tight market having a different effect during the crisis period. ${ }^{31}$ However, even after this interaction term is included, both the frequency of borrowing from a particular lender as well as the frequency of a reciprocal transaction significantly increase the probability of a new loan agreement between the two counterparties. In Model (4), we also include the interaction of the relationship variable with the second search friction proxy that indicates days with low market activity. While the coefficient of the interaction term is not significant, we find that during the crisis period bank pairs with a prior established relationship are less likely to transact a loan on days with low market activity.

In Model (5), we add as further control variables the surplus that the borrower realized in previous transactions with the respective lender and the surplus that the lender realized from past loans made to this borrower. We find no statistically significant evidence that the mutual surplus from a trading relationship increases the frequency of interaction among a bank pair. On the contrary, we find that during the pre-crisis period, a lower surplus extracted by the borrower in trades with a particular lender increases the probability that this pair will conclude another interbank loan. Surprisingly, however, this effect was significantly weaker during the crisis period. As additional controls for search frictions, in Model (5) we also include the correlation of the borrower's and the lender's liquidity positions to capture how likely it is that a pair of banks will benefit from trading with each other. We also allow for this search cost-related variable to have a nonlinear effect across the pre-crisis and crisis periods. While we do not find that banks have a significantly higher probability of lending to each other if they have a more negatively correlated liquidity position during the pre-crisis or the crisis periods, the frequency of past interactions still has a significantly positive effect on the probability that a bank pair will engage in a new loan, even after controlling for all these effects on search frictions.

In sum, we find that both the frequency of past lending relationships and reciprocal lending

\footnotetext{
${ }^{31}$ Note that the level effect of our aggregate search friction proxies, as well as the crisis variable, are absorbed in the day fixed effect.
} 
relationships play an important role in determining whether a new loan is granted between a pair of banks. Thus, established lending relationships and reciprocal relationships are important factors in improving a bank's access to liquidity. The inclusion of various control variables that capture different facets of search frictions does not change the significant impact of lending relationships on the matching probability. ${ }^{32}$

After establishing that relationship lending has a positive effect on the probability of a loan, we next examine the effect that relationship lending has on the bilateral interest rate, conditional on a loan being observed. Models (6) to (11) present the second-stage parameter estimates of the interest rate regression using the the inverse Mills ratio to correct for sample selection. The selection equation for all models consists of the full model for the matching probability depicted in Model (5).

Conditional on obtaining an interbank loan, we find that borrowers pay a significantly lower spread to lenders with whom they have had a previous trading relationship. Economically, the estimated coefficient in Model (6) suggests that a bank pair that interacted on any given day in the past month will agree on an interest rate that is about 12.9 bps $(-3.767 \times(\log (31)-\log (1)))$ lower than the spread agreed on by a bank pair which did not trade during the prior 30-day period. Similarly, the reciprocal relationship variable, Reciprocal_ $R L$, also has a significant negative effect on the interest rate spread, although the economic magnitude of this effect is substantially lower. Thus, banks that trade liquidity more frequently with each other trade at lower interest rates. ${ }^{33}$

Model (7) includes as an additional variable the relationship measure interacted with the crisis dummy. Particularly during periods of elevated uncertainty, we find that a relationship lender in the interbank market provides liquidity at a significantly lower rate than do arm's-length interbank lenders (with spreads as much as 3.3 bps lower, $-0.954 \times(\log (31)-\log (1)))$. In Model (8), we investigate if bank-pair relationships might be particularly important during times when there are relatively few lenders in the market. However, we do not find evidence that established credit relationships are more important for the pricing of interbank liquidity during times when the interbank market is tight. Neither in the pre-crisis nor in the crisis periods did established lending relationships mitigate the mark-up that a borrower had to pay when market conditions are tighter. In Model (9), we include the second proxy for search frictions and find that during the crisis period, relationship pairs indeed agreed on lower interest rates than arm's-length lenders on days with low market activity. However, this finding neither qualitatively nor quantitatively changes our key results that relationship lending mattered more during the crisis.

In Model (10), as an additional control for search frictions, we include the correlation of the

\footnotetext{
${ }^{32}$ The quantitative effects are also quite large. For instance, computing the upper bound of the marginal effect of $R L, \phi\left(w^{*} \beta\right) \beta_{R L}$, gives approximately $0.4 \cdot 0.791=0.316$, since $\phi\left(x^{*^{\prime}} \beta^{*}\right) \leq 1 / \sqrt{2 \pi} \simeq 0.4$ with maximum at $x^{*^{\prime}} \beta^{*}=0$.

${ }^{33}$ Note that these estimates take into account for potential sample selection, and indeed the significant coefficient of the inverse Mills ratio suggests that such a correction is statistically relevant.
} 
liquidity holdings for the respective pair of banks and the past surplus that each bank extracted from the relationship. Interestingly, our results suggest that a borrower actually pays a mark-up when receiving an overnight loan from a lender experiencing a negatively correlated liquidity shock. ${ }^{34}$ While one could expect that during the crisis period these search frictions were more important, we do not find that the negative correlation of liquidity positions had a significantly different effect during the crisis period. Moreover, we find that borrowers that obtain a large surplus from a specific lender, relative to other interbank lenders, paid significantly higher interest rates during the crisis. Most importantly, however, the inclusion of these control variables for search frictions does not change the effect of our key variables of interest: the negative effect on the spread at which a borrower obtains liquidity when borrowing from a frequent lender and when receiving funds from a lender to whom the bank has frequently granted loans remains qualitatively and quantitatively unchanged. Moreover, established credit relationships have a particularly mitigating effect on the interest rate spread when the loan decision is made during a period of elevated credit risk uncertainty, i.e., during the crisis.

Finally, Model (11) includes daily time fixed effects, lender fixed effects, and time-varying borrower fixed effects at a monthly frequency. These three sets of fixed effects permit us to control for almost any unobserved variation in a bank's characteristics that affects its borrowing rate. Even using this specification, our key result prevails: relationship lenders provide liquidity to their borrowers at an economically and statistically significant discount during crisis times.

In sum, for the interest rate spread, we find strong evidence suggesting that established lending relationships in the interbank market matter because they mitigate informational asymmetry about counterparty credit risk. This interpretation is strengthened by our finding that established relationships have a particularly strong effect on the interest rate spread during the crisis period when uncertainty about bank default risks was most severe. ${ }^{35}$

\subsection{Relationship Lending and Borrower-Level Opacity}

In the previous subsection, we have analyzed the effects of relationship lending on the availability and pricing of interbank credit under different aggregate market conditions related to search frictions and credit risk uncertainty during the 2007 crisis in the German interbank market. We now discuss how lending relationships affect borrowers that suffer from particularly severe asymmetric information problems. To do so, we include several measures of opacity at the borrower-level in our models and

\footnotetext{
${ }^{34}$ One possible explanation for these findings is that banks with positively correlated liquidity shocks are more similar in their key business lines. If this similarity between a lender and a borrower leads to a better assessment of counterparty risk and to lower monitoring costs, the lender might be more inclined to lend to similar borrowers and might provide cheaper credit.

${ }^{35}$ See Flannery, Kwan, and Nimalendran (2013) for empirical evidence that uncertainty about banks' asset values increased during the crisis.
} 
interact these measures with the relationship variable. ${ }^{36}$

Table 5 presents the estimation results of the sample selection model (bilateral matching probabilities) and the bilateral interest rate models using our different measures for borrower opacity. In all matching models (Models 1-7), we include lender, borrower, and day fixed effects as well as time-varying bank controls, as discussed in the control variable section. In the interest rate models (Models 8-14), we include lender and day fixed effects, and time-varying borrower fixed effects at a monthly frequency, as well as time-varying bank controls. Estimating these models with time-varying borrower fixed effects ensures a strong identification of the effects of relationship lending for opaque borrowers. The inverse Mills ratio included in Model (8) is based on estimates from Model (1), that of Model (9) comes from Model (2), and so on. Note that due to data availability for CDS spreads, credit ratings, and balance sheet data, the number of observations differs between models $(1) /(8)$, $(2) /(9)$, and $(3)-(7) /(10)-(14) \cdot{ }^{37}$

Models (1) and (8) show the results when the proxy for borrower opacity is a dummy variable that indicates when the three rating agencies disagree about the solvency of a specific bank. Model (1) suggests that such a split rating does not change the probability of receiving an interbank loan: neither the level effect nor the interaction term with the relationship variable is significant. In contrast, for the pricing model tested in Model (8), we find that banks that are subject to a split credit rating pay significantly higher interest rate spreads. However, when borrowing from a relationship lender, these banks obtain credit at significantly lower spreads compared to what they would be charged by an arm's-length lender. The additional discount obtained from the relationship lender can be as high as 1.8 bps $(-0.523 \times(\log (31)-\log (1)))$.

Models (2) and (9) show the estimated selection equation that uses the borrower bank's variability in CDS spreads (measured by the coefficient of variation) as a proxy for uncertainty about borrower credit risk. Banks with a high volatility in CDS are subject to more changes in perceived credit risk, as indicated by changes in this market-based measure. For the selection equation in Model (2), the estimated coefficient of the CDS volatility is negative, but not statistically significant. However, from Model (9), once again we find that borrower opacity matters for the pricing of interbank loans. Borrowers with higher volatility in CDS spreads pay significantly higher interest rates for interbank credit. Yet, these opaque borrowers obtain credit at significantly lower spreads from their

\footnotetext{
${ }^{36}$ In robustness tests, we have also checked if the effects of relationship lending for opaque borrowers are different during the crisis period or during days with high search frictions; however, we did not find any significant results.

${ }^{37}$ We refrain from basing our analysis only on borrower banks for which all information on CDS spreads, credit ratings, and balance sheet data are jointly available, as this would significantly reduce the number of borrower banks in the sample. We observe CDS spreads for 15 different borrowers, credit ratings for 39 borrowers, and both CDS spreads and credit ratings for 11 borrowers (out of a total of 66 borrowers in the sample). Our results are not sensitive to the inclusion of balance sheet variables in the selection equation. When restricting the data to interbank loans where we observe both the CDS spread and the credit ratings for the borrowing bank, our main results remain robust and statistically significant.
} 
relationship lenders (the economic effects range up to $2 \mathrm{bps},-1.846 \times 0.4 \times(\log (31)-\log (1))) .{ }^{38}$

Selection Model (3) shows that a bank pair that is not part of a formal lending network (such as those comprised by Landesbanken and Sparkassen, or cooperative banks and their regional head institutions) has a significantly lower probability of lending to each other. However, the existence of a bilateral lending relationship can overcome this reduced access, as the positive and significant coefficient indicates. In Model (10), we present the results of our analysis of whether belonging to a formal network matters for the pricing of credit. Indeed, our findings suggest that if two banks are not members of a formal network, spreads on granted interbank loans are about 1.3 bps higher. Moreover, the estimated coefficient of the interaction term with the relationship lending variable is significantly negative, indicating that relationship lending matters more for credit relations between banks that are not part of a formal network. Economically, we estimate that borrowers obtain spreads that are up to 3.4 bps lower when borrowing from relationship lenders outside of their formal network, as compared to borrowing from spot lenders $(-0.976 \times(\log (31)-\log (1)))$. Hence, relationship lending matters more for the availability and pricing of credit between two banks that are not part of the formal network.

Next, we include interaction terms between the relationship variable and borrower opacity measures based on banks' monthly balance sheet data for the selection models (Models 4-7) and interest rate models (Models 11-14). We do not find that the balance sheet variables or interaction terms have a significant effect on the matching probability (debt is only marginally significant). However, for the pricing of interbank loans, our results in Model (11) show that borrowers with a larger fraction of loans to nonbanks on their balance sheets obtain interbank credit from their relationship lenders at significantly lower rates. Similarly, we find that banks that hold more cash relative to total assets pay significantly lower spreads for interbank loans from their relationship lenders (see Model 12). While we estimate positive coefficients for the interaction term between the relationship variable and either securities or debt, the effects are not statistically significant (Models 13 and 14). Recall that the level effects of the monthly balance sheet variables are absorbed because we allow for time-varying borrower fixed effects at a monthly frequency to obtain a strong identification of relationship effects.

In sum, our analysis of the interaction between interbank relationship lending and borrower opacity shows that bank-pair relationships matter for the pricing of credit, specifically in a situation when the borrower is opaque and its credit quality is hard to assess. Our finding that relationship lenders provide credit at lower spreads to opaque borrowers is in line with the theory suggesting that relationship lending mitigates the problem of asymmetric information and reduces the lemon

\footnotetext{
${ }^{38}$ We have also checked if the level of the CDS spread matters (instead of the volatility) for the relationship effect by including the level of the CDS spread and the interaction with the relationship variable, but did not find any significant results. Again, this result shows that credit-risk uncertainty matters.
} 
premium imposed by lenders. Therefore, the results for borrower opacity complements the finding that relationships matter, particularly during times of elevated credit-risk uncertainty resulting from the 2007 financial crisis.

\subsection{Robustness Checks}

This section presents several robustness checks to our main analysis. Using the interbank relationship measures that capture the intensity of relationships, i.e., the interbank borrowing and lending concentration (LPI/BPI), Table 6 shows the results for relationship lending and aggregate market conditions; the table follows the same logic as Table 4. In sum, for the lending concentration index LPI, we find results similar to the frequency measure RL (which seems reasonable given the high correlation between the two variables): during the financial crisis, relationship lenders (lenders with a higher lending concentration toward a particular borrower) grant lower rates to borrowers with whom they have established relationships. ${ }^{39}$ In contrast, banks with a highly concentrated borrowing portfolio - a high BPI - pay higher rates to their closest lenders. Interestingly, however, we find that bank pairs with a high BPI agree on lower rates on days characterized by high search frictions (measured either by market tightness or the number of transactions). This finding supports the view that bank pair relationships also help to insure against search frictions in addition to mitigating asymmetric information problems about credit risk.

Our overall conclusions about the effects of relationship lending and borrower opacity are robust to other relationship measures, as shown in Table 7. In particular, high LPI lenders grant interbank loans at lower spreads to their closest borrowers if these banks are subject to a split credit rating or their CDS spread volatility is high. Interestingly, for interbank loans outside of a formal network, the borrowing bank's borrowing concentration matters significantly and quantitatively more than the lending bank's lending concentration. The results for the interaction of the relationship variable with the other bank opacity measures also have the expected signs, but these lack significance. ${ }^{40}$

Our analysis of the effect of relationship lending for opaque borrowers relies on bank characteristics that we do not have for non-German borrowers. However, we also extend our analysis to a sample that includes interbank loans from foreign (non-German) lender banks granted to German borrower banks. Using these sample estimations confirms our main findings. Loans between bank pairs with an established relationship had lower interest rates during the crisis period, and when the borrower's credit worthiness is harder to assess. This finding is also true when including loans granted from foreign (i.e., non-German) lenders for which we do not have any lender-specific information. For an

\footnotetext{
${ }^{39}$ Note that the significance of this result is lost when time-varying borrower fixed effects are included.

${ }^{40}$ Note, however, that these regressions include time-varying borrower fixed effects that control for almost any variation at the borrower level. In fact, estimating these models by only using borrower fixed effects restores the significance in most cases.
} 
in-depth analysis of cross-border lending in the euro area, see Abbassi, Bräuning, Fecht, and Peydró (2015).

\section{Conclusion}

Our analysis focuses on interbank relationship lending between German banks for which we have a comprehensive set of control variables constructed, among others, from balance sheet and reserve holdings data. Our main results show that established lending relationships matter both for the availability and the pricing of interbank liquidity. Being able to control for the effect that relationships play in mitigating search frictions, we show that relationship lending in the interbank market also matters, as it helps to alleviate informational asymmetries regarding counterparty credit risk. Specifically, in times of elevated market-wide uncertainty about counterparties' credit risk as well as for loans to opaque borrowers, our result suggest that established lending relationships in the interbank market are an important factor in mitigating the lemons problem. These findings have three important implications. First, there are potential benefits from a decentralized unsecured interbank market structure that need to be balanced against the larger systemic risks of having such a market structure. Second, the failure of a bank may affect not only its lenders in the interbank market network but also its borrowers if the failed bank has been a relationship lender to other banks; hence, in addition to the traditional contagion channel, a bank failure may trigger contagion through a bank's asset side. Third, our finding that the network of interbank overnight relationships is very persistent means that counterfactual contagion analyses and the identification of systemically important financial institutions can be based on interbank data with a relatively small time dimension.

\section{REFERENCES}

Abbassi, Puriya, Falk Bräuning, Falko Fecht, and José Luis Peydró. 2015. "Cross-Border Liquidity, Relationships and Monetary Policy: Evidence from the Euro Area Interbank Crisis." CEPR Discussion Paper No. 10479. London: Centre for Economic Policy Research.

Acharya, V. V., and David Skeie. 2011. "A Model of Liquidity Hoarding and Term Premia in Inter-bank Markets." Journal of Monetary Economics 58 (5):436-447.

Affinito, Massimiliano. 2012. "Do Interbank Customer Relationships Exist? And How Did They

Function Over the Crisis? Learning from Italy." Journal of Banking and Finance 36 (12):3163-3184.

Afonso, Gara, Anna Kovner, and Antoinette Schoar. 2011. "Stressed, Not Frozen: The Federal Funds Market in the Financial Crisis." Journal of Finance 66 (4):1109-1139. 
Afonso, Gara, Anna Kovner, and Antoinette Schoar. 2014. "Trading Partners in the Interbank Lending Market." Staff Reports, No. 620. New York: Federal Reserve Bank of New York.

Ashcraft, Adam B., and Darrell Duffie. 2007. "Systemic Illiquidity in the Federal Funds Market." The American Economic Review 97 (2):221-225.

Babus, Ana. 2011. "Strategic Relationships in Over-the-Counter Markets." Mimeo.

Bech, Morten, and Enghin Atalay. 2010. "The Topology of the Federal Funds Market." Physica A 389 (22):5223-5246.

Bech, Morten, and Cyril Monnet. 2016. "A Search-Based Model of The Interbank Market and Monetary Policy Implementation." Journal of Economic Theory 164 (C):32-67.

Bech, Morten L., and Elizabeth Klee. 2011. "The Mechanics of a Graceful Exit: Interest on Reserves and Segmentation in the Federal Funds Market." Journal of Monetary Economics 58 (5):415-431.

Berger, Allen N., and Gregory F. Udell. 1995. "Relationship Lending and Lines of Credit in Small Firm Finance." Journal of Business 68 (3):351-81.

Blasques, Francisco, Falk Bräuning, and Iman van Lelyveld. 2016. "A Dynamic Network Model of the Unsecured Interbank Lending Market." Working Paper No. 16-3. Boston: Federal Reserve Bank of Boston.

Boot, Arnoud W. A. 2000. "Relationship Banking: What Do We Know?" Journal of Financial Intermediation 9 (1):7-25.

Broecker, Thorsten. 1990. "Credit-Worthiness Tests and Interbank Competition." Econometrica $58(2): 429-52$.

Bundesbank. 2005. TARGET-Leitfaden für Kreditinstitute.

Bundesbank. 2011. "Banking Statistics - Statistical Supplement to the Monthly Report June 2011."

Cocco, João F., Francisco J. Gomes, and Nuno C. Martins. 2009. "Lending Relationships in the Interbank Market." Journal of Financial Intermediation 18:24-48.

Craig, Ben R., Falko Fecht, and Günseli Tümer-Alkan. 2015. "The Role of Interbank Relationships and Liquidity Needs." Journal of Banking and Finance 53:99-111.

Craig, Ben R., and Goetz von Peter. 2014. "Interbank Tiering and Money Center Banks." Journal of Financial Intermediation 23 (3):322-347.

Degryse, Hans, and Steven Ongena. 2005. "Distance, Lending Relationships, and Competition." Journal of Finance 60 (1):231-266. 
Duffie, Darrell, Nicolae Garleanu, and Lasse Heje Pedersen. 2005. "Over-the-Counter Markets." Econometrica 73 (6):1815-1847.

ECB. 2013. "Financial Stability Review, December 2007."

Fecht, Falko, Hans Peter Grüner, and Philipp Hartmann. 2012. "Financial Integration, Specialization, and Systemic Risk." Journal of International Economics 88 (1):150-161.

Fecht, Falko, Kjell G. Nyborg, and Jörg Rocholl. 2011. "The Price of Liquidity: The Effects of Market Conditions and Bank Characteristics." Journal of Financial Economics 102 (2):344-362.

Flannery, Mark J. 1996. "Financial Crises, Payment System Problems, and Discount Window Lending." Journal of Money, Credit and Banking 28 (4):804-24.

Flannery, Mark J., Simon H. Kwan, and Mahendrarajah Nimalendran. 2013. "The 2007-2009 Financial Crisis and Bank Opaqueness." Journal of Financial Intermediation 22 (1):55-84.

Freixas, Xavier, and Cornelia Holthausen. 2005. "Interbank Market Integration under Asymmetric Information." Review of Financial Studies 18 (2):459-490.

Freixas, Xavier, and José Jorge. 2008. "The Role of Interbank Markets in Monetary Policy: A Model with Rationing." Journal of Money, Credit and Banking 40 (6):1151-1176.

Furfine, Craig H. 1999. "The Microstructure of the Federal Funds Market." Financial Markets, Institutions \& Instruments 8 (5):24-44.

Furfine, Craig H. 2001. "Banks as Monitors of Other Banks: Evidence from the Overnight Federal Funds Market." Journal of Business 74 (1):33-57.

Hauswald, Robert, and Robert Marquez. 2003. "Information Technology and Financial Services Competition." Review of Financial Studies 16 (3):921-948.

Heckman, James J. 1979. "Sample Selection Bias as a Specification Error." Econometrica 47 (1):15361.

Heider, Florian, Marie Hoerova, and Cornelia Holthausen. 2015. "Liquidity Hoarding and Interbank Market Spreads: The Role of Counterparty Risk." Journal of Financial Economics 118 (2):336-354.

Heijmans, Ronald, Richard Heuver, and Daniëlle Walraven. 2011. "Monitoring the Unsecured Interbank Money Market Using TARGET2 Data." DNB Working Papers No. 276. Amsterdam: De Nederlandsche Bank.

Ho, Thomas S Y, and Anthony Saunders. 1985. "A Micro Model of the Federal Funds Market." Journal of Finance 40 (3):977-88. 
Jewell, Jeff, and Miles Livingston. 1999. "A Comparison of Bond Ratings from Moody's S\&P and Fitch IBCA." Financial Markets, Institutions 8 Instruments 8 (4):1-45.

Morgan, Donald P. 2002. "Rating Banks: Risk and Uncertainty in an Opaque Industry." American Economic Review 92 (4):874-888.

Nieuwerburgh, Stijn Van, and Laura Veldkamp. 2010. "Information Acquisition and UnderDiversification." Review of Economic Studies 77 (2):779-805.

Petersen, Mitchell A., and Raghuram G. Rajan. 1994. "The Benefits of Lending Relationships: Evidence from Small Business Data." Journal of Finance 49 (1):3-37.

Petersen, Mitchell A., and Raghuram G. Rajan. 1995. "The Effect of Credit Market Competition on Lending Relationships." Quarterly Journal of Economics 110 (2):407-43.

Petersen, Mitchell A., and Raghuram G. Rajan. 2002. "Does Distance Still Matter? The Information Revolution in Small Business Lending." Journal of Finance 57 (6):2533-2570.

Rajan, Raghuram G. 1992. "Insiders and Outsiders: The Choice between Informed and Arm's-Length Debt." Journal of Finance 47 (4):1367-400.

Rochet, Jean-Charles, and Jean Tirole. 1996. "Interbank Lending and Systemic Risk." Journal of Money, Credit and Banking 28 (4):733-762.

Sharpe, Steven A. 1990. "Asymmetric Information, Bank Lending, and Implicit Contracts: A Stylized Model of Customer Relationships." Journal of Finance 45 (4):1069-87.

Simensen, Ivar, and Ralph Atkins. 2007. "Subprime hits German state banks." Financial Times 21. August 2007, http://www.ft.com/cms/s/0/178cbd98-5014-11dc-a6b0-0000779fd2ac.html.

Wetherilt, Anne, Peter Zimmerman, and Kimmo Soramaki. 2010. "The Sterling Unsecured Loan Market During 2006-08: Insights from Network Theory." Working Paper No. 398. London: Bank of England. 


\section{A Institutional BaCkground}

\section{A.1 Liquidity and the Interbank Market in the Euro Area}

In the primary market for liquidity, the European Central Bank (ECB) lends money to banks against collateral through open market operations, namely regular weekly main refinancing operations (MRO), monthly longer-term refinancing operations (LTRO), and fine-tuning as well as structural operations. During our sample period from March 2006 through November 2007, the MROs were conducted on a weekly basis as variable tender operations with a minimum bid rate, which is commonly called the target rate. In addition to these open market operations, the ECB provides two standing facilities for banks to manage liquidity. At the marginal lending facility, banks can borrow overnight from the central bank against collateral at a penalty rate, which was 100 bps above the minimum bid rate during our sample period. The deposit facility allows banks to invest overnight excess liquidity at a rate which was 100 bps below the minimum bid rate during our sample period. During the day banks can borrow at a zero interest rate from the ECB, but only against eligible collateral.

A bank's need to borrow from the central bank is driven by liquidity shocks that result from their day-to-day business operations, such as the need to pay for an asset or to pay customers withdrawing their deposits. These business-related factors are embedded in a regulatory framework that also affects a bank's liquidity demand. In particular, the ECB requires a bank to hold a fraction of its short-term liabilities on its account at the central bank. These reserve requirements must be fulfilled on average during the maintenance period that usually lasts four weeks. Moreover, at the end of the day, negative reserve balances force banks to borrow through the marginal lending facility at a penalty rate. Thus, a bank tries to avoid having negative end-of-day balances and targets compliance with the reserve requirements on the last day of the maintenance period.

When managing its liquidity, a bank does not solely depend on reserves that it can borrow directly from the ECB. In the secondary market, banks reallocate liquidity among themselves through either unsecured or secured lending, the latter typically in the form of repo transactions. In normal times, unsecured lending is relatively more attractive since there is no need to use costly collateral and interest rates for unsecured overnight loans (by far the most commonly traded maturity ${ }^{41}$ ) typically fall in between the corridor rates set by the interest rates of the standing facilities.

\footnotetext{
${ }^{41}$ For instance, Heijmans, Heuver, and Walraven (2011) find that more than 82 percent of total credit in the Dutch unsecured money market has overnight maturity.
} 


\section{A.2 Structure of the German Banking System}

The German banking system is traditionally a system of universal banking (not distinguishing between investment and commercial banking) and has a three-pillar structure. The first pillar, comprised by the private domestic banks, accounted for about 36 percent of the entire banking sector's total balance sheet as of June 20, 2011. The second pillar is formed by the public banks, comprised by the savings banks and the savings banks' regional head institutions, the Landesbanken, which are jointly owned by the respective state and the regional association of savings banks. This second banking group makes up 31 percent of the German banking sector. The cooperative banking sector, composed of the credit cooperatives and the cooperative central banks (the latter being primarily owned by the regional credit cooperatives), constitute the third pillar, and accounts for 19 percent of the German banking sector's assets under management. ${ }^{42}$

This three-pillar structure affects the way that liquidity is reallocated in the banking sector. The public banks as well as the cooperative banking sector form a relatively closed giro system (a system in which money can be transferred from one account to another). On average, the second-tier

institutions - the savings banks and the credit cooperatives - typically achieve a significant liquidity surplus due to their retail business structure. Within the giro system, those second-tier institutions with excess liquidity lend to their respective head institution which re-distributes the liquidity to second-tier institutions that are short in liquidity. Thus savings (i.e., public) and cooperative banks may have less of a need to participate directly in the interbank market for reserves than private banks because they rely on formal relationship networks within their respective sector.

In general and not only due to this three pillar structure the German interbank loan market has a core-periphery network structure. Within this structure, the highly interconnected money center, core banks are the Landesbanken, the cooperative central banks and the large commercial banks, while particularly those banks with a strong regional retail focus are in the periphery that is typically only connected to few core banks (see Craig and von Peter 2014).

\section{B Extracting Overnight Loan Information from Payment DATA}

We use a computer algorithm similar to Furfine $(1999,2001)$ to extract unsecured overnight interbank loans from interbank payments settled in RTGSplus the German portion of the TARGET system,

\footnotetext{
${ }^{42}$ Besides those major banking groups, special purpose banks and buildings societies (Bausparkassen) and branches of foreign banks operating in Germany are the remaining groups of banks. All figures are taken from Bundesbank (2011).
} 
the Eurosystem's large value payment system. ${ }^{43}$ TARGET operated from 2001 until the end of 2007 and consisted of connected, national payment systems including RTGSplus, which was run by the Deutsche Bundesbank. The main part of large value payments include payments for interbank loans and other assets, but liquidity provision by central banks also is settled in these systems.

Each payment record contains information about the amount sent, date, and time of the transaction, and the Bank Identifier Code (BIC) of the ordering and receiving bank that uniquely identifies each institution. For a more detailed description of the RTGSplus, see Bundesbank (2005). We do not observe the reason for the individual payment and thus cannot identify interbank loans directly from the transactions. However, given the information for each payment, it is possible to identify unsecured overnight interbank loans by an algorithm that searches for payments from bank $i$ to bank $j$ on day $t$, and searches for a reverse payment (from bank $j$ to bank $i$ ) on the next day $t+1$ of a slightly higher value; the increase corresponds to a plausible overnight interest payment. This also means that we can infer the respective interest rate by $i_{i, j, t}=\left(\right.$ payment $_{j, i, t+1} /$ payment $\left._{i, j, t}-1\right) \cdot 360^{44}$, where payment $_{i, j, t}$ are the amount of the payment legs related to an overnight loan.

In a seminal article, Furfine (1999) used interbank payment data from the Fedwire system in order to identify interbank loans. As loans are typically granted in round amounts, he considered restriction on the loan amounts, and used a 'plausibility corridor' for the interest rate based on the fed funds rate. Recently, Heijmans, Heuver, and Walraven (2011) have adapted and considerably refined the Furfine algorithm for the the European interbank market by defining a 'plausibility corridor' based on EONIA. ${ }^{45}$ In this paper, we follow their improved identification algorithm. Specifically, we consider amounts of at least EUR 1 million and increments of EUR 100,000 and adopt the plausibility corridor for overnight loans proposed by Heijmans, Heuver, and Walraven (2011) with 50 bps below and above EONIA during our sample period.

Of course, we cannot be completely sure that this method really identifies all interbank overnight loans and does not erroneously match two payments unrelated to an interbank loan. The tradeoff between incorrectly identifying two transactions as an overnight loan and missing an overnight loan is affected by the algorithm's parameters, especially the width of the plausibility corridor. A particular problem occurs if one specific payment has more than one refund match (1:N match), or if there are several payments but only one refund is found (M:1 match). In our data, we found a small number of such multiple matches (486) and we decided to take the first (return) transaction to identify a loan. Theoretically, M:N matches are also possible but we did not encounter them in our data.

Despite these intrinsic problems the method seems to work well in identifying interbank overnight

\footnotetext{
${ }^{43}$ RTGSplus is an acronym for Real Time Gross Settlement Plus and TARGET for Trans-European Automated Real-time Gross settlement Express Transfer system.

${ }^{44}$ We compute interest rates per annum based on 360 days, analogously to EONIA.

${ }^{45}$ EONIA (Euro OverNight Index Average) is an effective overnight interbank market rate based on a sample of 35 large banks
} 
loans especially for our sample period; compare Furfine (2001) and Heijmans, Heuver, and Walraven (2011) for an in depth evaluation. ${ }^{46}$ For our application, the plausibility corridor of EONIA +/- 50 bps does not seem to be a binding constraint. Using a considerably larger corridor around EONIA of up to $+/-10$ percentage points increases the number of identified interbank loans only by slightly less then 0.9 percent. In particular, about 180 additional candidate interbank loans fall outside the +/- 50 bps corridor relative to 20,819 loans identified with the narrow corridor. Furthermore, a visual inspection of the loans outside the corridor suggests that they are not clustered in the crisis period or related to any borrower characteristic.

In contrast to most other publicly available dataset (such a credit registry data from some countries), a big advantage of our data is that we have transaction-level data on unsecured interbank loans that includes both the interest rate and the volume of granted loans. Moreover, our data not only include loans from very large banks as the EONIA panel does, but is a more comprehensive dataset with respect to the cross-sectional dimension of the population. ${ }^{47}$

For our main analysis, we use the transaction-level data to construct a panel dataset with days as the time unit and bank pairs as the cross-sectional unit. Since we have identified transaction-level data from the payment records we aggregate multiple loans on the same day for the same bank pair to one observation and compute a volume-weighted average interest rate $i_{i, j, t}$. In our final panel dataset, 844 observations contain more than one loan, with the largest number of loans per day between the same banks is 17 .

\footnotetext{
${ }^{46}$ We refrain from running the algorithm for longer-term loans, as the assessment by Heijmans, Heuver, and Walraven (2011) indicates that the algorithm does much worse in identifying loans with higher maturity.

${ }^{47}$ In May 2007, RTGSplus had 194 direct participants, including all major German banks by asset size. Besides RTGSplus, cooperative banks and savings banks run their own payment systems and exchange liquidity with other banking sectors often through their central institutes only. Therefore our sample contains relatively few bank from these sectors.
} 


\section{Figures}

Figure 1: Average Daily Interest Rate, EONIA and ECB Target Rate

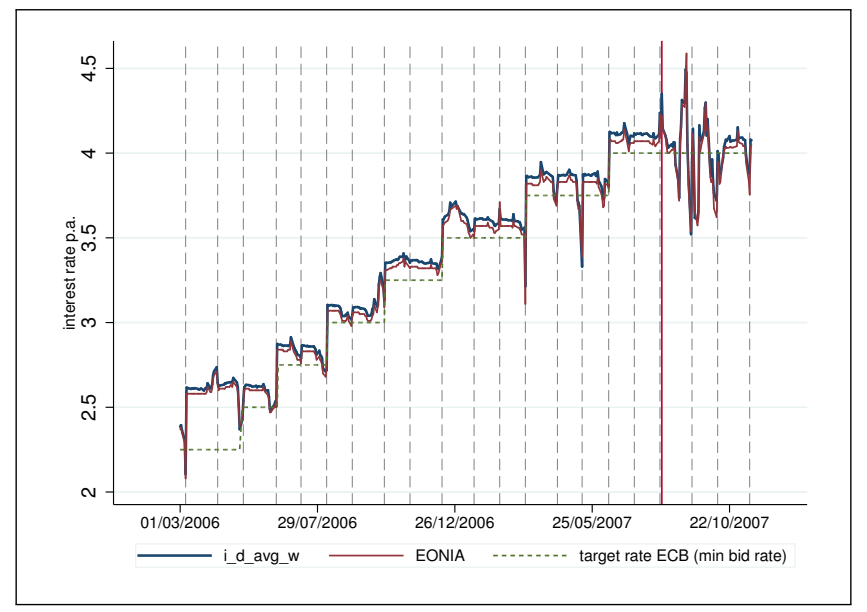

Notes: This figure depicts 'i_d_avg_w', the volume-weighted average overnight interest rate from our panel dataset. For comparison also the 'EONIA' rate (Euro OverNight Index Average) and the 'target rate ECB', i.e., the minimum bid rate at main refinancing operations are depict. Vertical dashed lines (in gray) indicate end of maintenance period, vertical solid line (in red) indicates start of the financial crisis on August 9, 2007.

Source: Authors' calculations. 
Figure 2: Number of Lending and Borrowing Banks

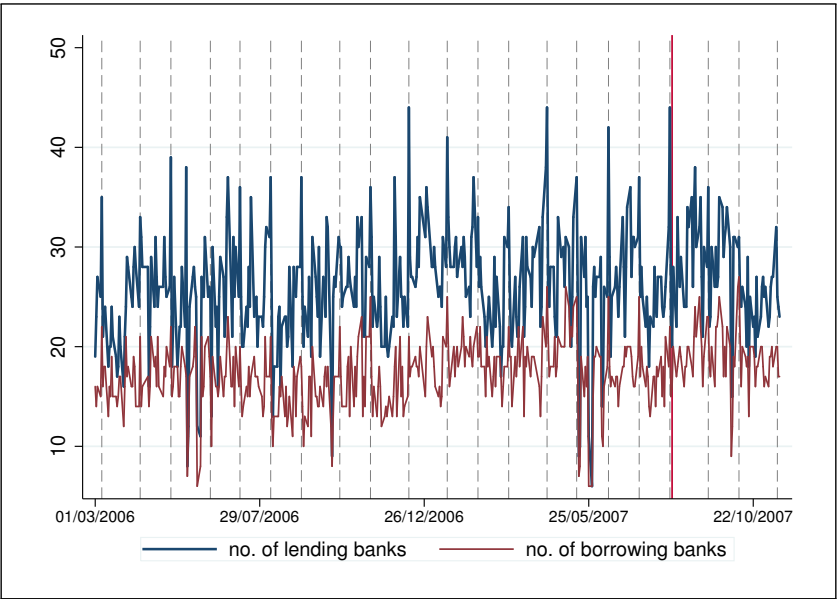

Notes: This figure depicts the daily number of lending and borrowing banks in the sample. Vertical dashed lines (in gray) indicate end of maintenance period, vertical solid line (in red) indicates start of the financial crisis on August 9, 2007.

Source: Authors' calculations.

Figure 3: Total Amount and Total Number of Granted Loans

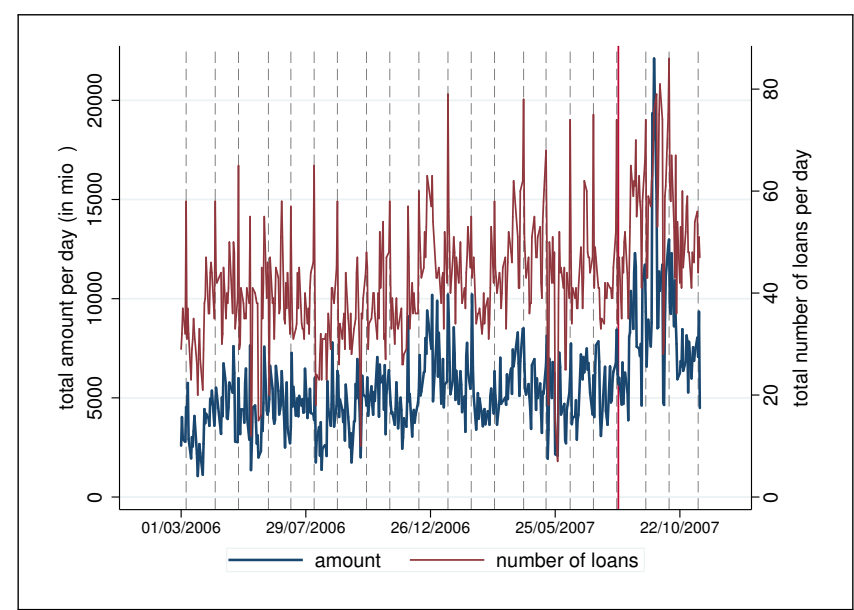

Notes: This figure depicts the daily total amount of all granted loans (in EUR millions) and the daily total number of granted loans. Vertical dashed lines (in gray) indicate end of maintenance period, vertical solid line (in red) indicates start of the financial crisis on August 9, 2007.

Source: Authors' calculations. 
Figure 4: Market Tightness

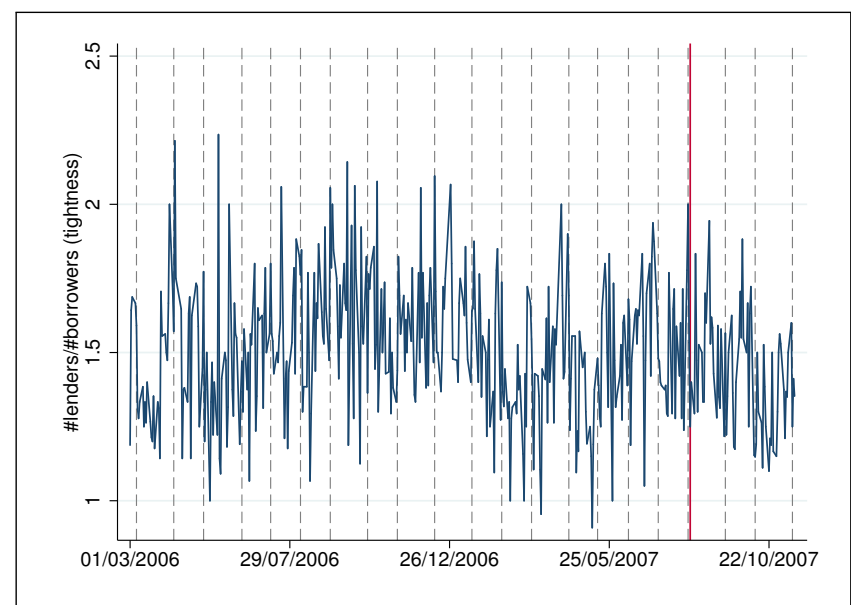

Notes: Market Tightness Defined as Number of Lenders Per Day Divided by Number of Borrowers Per Day. Vertical dashed lines (in gray) indicate end of maintenance period, vertical solid line (in red) indicates start of the financial crisis on August 9, 2007.

Source: Authors' calculations. 


\section{TABLES}

Table 1: Mean Comparison Test for Aggregate Variables.

\begin{tabular}{lcccc}
\hline & \multicolumn{2}{c}{ Daily Mean } & & \\
& Crisis $=0$ & Crisis $=1$ & Difference & $t$-Statistic \\
\hline \# Granted Loans & 40.87 & 54.81 & -13.93 & $-8.87^{* *}$ \\
Total Volume of Granted Loans & $5,042.38$ & $8,595.93$ & $-3,553.55$ & $-8.92^{* *}$ \\
Average Amount of Granted Loans & 124.70 & 155.41 & -30.72 & $-6.35^{* *}$ \\
Average Spread of Granted Loans & 0.11 & -0.00 & 0.11 & $4.43^{* *}$ \\
EONIA spread & 0.08 & 0.00 & 0.08 & $3.76^{* *}$ \\
Stdev of Spreads of Granted Loans & 0.03 & 0.09 & -0.06 & $-7.37^{* *}$ \\
\# Lending Banks & 25.91 & 27.18 & -1.27 & -1.84 \\
\# Borrowing Banks & 17.11 & 19.08 & -1.97 & $-4.98^{* *}$ \\
Market Tightness & 1.52 & 1.43 & 0.09 & $3.22^{* *}$ \\
Total Reserve Holdings & $20,781.60$ & $22,380.36$ & $-1,598.76$ & -1.45 \\
\hline
\end{tabular}

Notes: Mean comparison test of daily variables before and during the crisis and mean difference (Crisis $=1$ after August 9, 2007). The $t$-statistic corresponds to $H_{0}:$ diff $=0$ and is based on unequal variances. All amounts reported in EUR millions and interest rate spreads are expressed as difference to MRO rate in percentage. 'Stdev of Spreads of Granted Loans' is the daily cross-sectional standard deviation of interest rates of granted loans. 'Market Tightness' is daily number of lending banks divided by number of borrowing banks. ${ }^{*} p<0.05,{ }^{* *} p<0.01$ 
Table 2: Summary Statistics of Relationship Variables by Asset Size.

\begin{tabular}{|c|c|c|c|c|c|c|c|}
\hline & \# Borrowers & \# Lenders & $\begin{array}{l}\text { \# Loans As } \\
\text { Lender }\end{array}$ & $\begin{array}{c}\text { \# Loans As } \\
\text { Borrower }\end{array}$ & Amount Lent & $\begin{array}{c}\text { Amount } \\
\text { Borrowed }\end{array}$ & Net Position \\
\hline \multicolumn{8}{|c|}{ Banks with EUR 0-1 Billions of Total Assets } \\
\hline Mean & 6.53 & 1.46 & 349.84 & 27.15 & 14.41 & 0.19 & 14.22 \\
\hline Min & 1 & 0 & 16 & 0 & 0.08 & 0 & -1.21 \\
\hline Max & 12 & 4 & 1,579 & 181 & 90.22 & 1.29 & 90.22 \\
\hline \multicolumn{8}{|c|}{ Banks with EUR 1-10 Billions of Total Assets } \\
\hline Mean & 9.25 & 3.55 & 190.75 & 29.15 & 13.93 & 2.18 & 11.76 \\
\hline Min & 0 & 0 & 0 & 0 & 0 & 0 & -2.16 \\
\hline $\operatorname{Max}$ & 24 & 12 & 830 & 105 & 106.90 & 26.64 & 106.90 \\
\hline \multicolumn{8}{|c|}{ Banks with EUR 10-100 Billions of Total Assets } \\
\hline Mean & 16.79 & 16.48 & 171.21 & 177.90 & 26.32 & 20.50 & 5.82 \\
\hline Min & 4 & 0 & 19 & 0 & 0.83 & 0 & -196.69 \\
\hline $\operatorname{Max}$ & 28 & 46 & 618 & 1,233 & 116.49 & 204.33 & 109.93 \\
\hline \multicolumn{8}{|c|}{ Banks with More Than EUR 100 Billions of Total Assets } \\
\hline Mean & 21.47 & 34.10 & 214.40 & 696.60 & 79.57 & 118.83 & -39.25 \\
\hline Min & 11 & 0 & 21 & 0 & 4.19 & 0 & -293.20 \\
\hline Max & 36 & 57 & 641 & 1,807 & 377.24 & 306.01 & 368.26 \\
\hline
\end{tabular}

Notes: Out of the 77 banks in our sample, there are 13 banks with total assets of smaller than EUR 1 billion, 20 banks with EUR 1-10 billions, 29 banks with EUR 10-100 billions, and 15 banks with more than EUR 100 billions. The '\# Borrowers' is the number of different borrowers a bank lent to, '\# Lenders' is the number of banks a bank borrowed from. '\# Loans as Lender' ('\# Loans as Borrower') depicts how often a bank acted as a lender (borrower) in the market. 'Amount Lent' ('Amount Borrowed') are the total amount lent (borrowed) in EUR billions, net position is amount lent minus amount borrowed. All figures are based on market activity in the our sample.

Table 3: Correlation Table of Relationship Variables.

\begin{tabular}{lcccc} 
& $\mathrm{RL}_{i, j, t}$ & Reciprocal_RL & $\mathrm{LPI}_{i, j, t}$ & $\mathrm{BPI}_{i, j, t}$ \\
\hline $\mathrm{RL}_{i, j, t}$ & 1.00 & & & \\
Reciprocal_RL $\mathrm{RL}_{i, j, t}$ & 0.05 & 1.00 & & \\
$\mathrm{LPI}_{i, j, t}$ & 0.69 & 0.07 & 1.00 & \\
$\mathrm{BPI}_{i, j, t}$ & 0.48 & 0.15 & 0.31 & 1.00 \\
\hline
\end{tabular}

Notes: The variables are defined in Equations (1) to (4). All correlations are significant at the 5 percent level. 
Table 4: Relationship Lending and Aggregate Market Conditions.

\begin{tabular}{|c|c|c|c|c|c|c|c|c|c|c|c|}
\hline & \multicolumn{5}{|c|}{ Matching Probabilities: $P\left(\operatorname{Loan}_{i, j, t}=1\right)$} & \multicolumn{6}{|c|}{ Interest Rate Models: Spread $_{i, j, t}$} \\
\hline & (1) & $(2)$ & (3) & (4) & $(5)$ & (6) & $(7)$ & $(8)$ & (9) & $(10)$ & $(11)$ \\
\hline $\mathrm{RL}_{i, j, t}$ & $\begin{array}{c}0.773^{* * *} \\
(29.84)\end{array}$ & $\begin{array}{c}0.777^{* * *} \\
(27.08)\end{array}$ & $\begin{array}{c}0.779^{* * *} \\
(27.62)\end{array}$ & $\begin{array}{c}0.780^{* * *} \\
(27.43)\end{array}$ & $\begin{array}{c}0.791^{* * *} \\
(25.66)\end{array}$ & $\begin{array}{c}-3.767^{* * *} \\
(-4.09)\end{array}$ & $\begin{array}{c}-2.970^{* * *} \\
(-3.61)\end{array}$ & $\begin{array}{c}-2.899^{* * *} \\
(-3.47)\end{array}$ & $\begin{array}{c}-2.582^{* * *} \\
(-3.12)\end{array}$ & $\begin{array}{c}-2.388^{* * *} \\
(-2.89)\end{array}$ & $\begin{array}{c}-1.693^{* *} \\
(-2.10)\end{array}$ \\
\hline Crisis $_{t} * \mathrm{RL}_{i, j, t}$ & & $\begin{array}{l}-0.021 \\
(-0.91)\end{array}$ & $\begin{array}{l}-0.027 \\
(-1.20)\end{array}$ & $\begin{array}{l}-0.025 \\
(-1.11)\end{array}$ & $\begin{array}{l}-0.021 \\
(-0.83)\end{array}$ & & $\begin{array}{c}-0.954^{* *} \\
(-2.33)\end{array}$ & $\begin{array}{c}-1.085^{* *} \\
(-2.03)\end{array}$ & $\begin{array}{l}-1.009^{*} \\
(-1.94)\end{array}$ & $\begin{array}{c}-1.044^{* *} \\
(-2.08)\end{array}$ & $\begin{array}{l}-0.896^{*} \\
(-1.91)\end{array}$ \\
\hline Tightness $_{t} * \mathrm{RL}_{i, j, t}$ & & & $\begin{array}{l}-0.012 \\
(-0.63)\end{array}$ & $\begin{array}{l}-0.011 \\
(-0.58)\end{array}$ & $\begin{array}{l}-0.010 \\
(-0.52)\end{array}$ & & & $\begin{array}{l}-0.029 \\
(-0.30)\end{array}$ & $\begin{array}{l}-0.031 \\
(-0.33)\end{array}$ & $\begin{array}{l}-0.035 \\
(-0.38)\end{array}$ & $\begin{array}{l}-0.080 \\
(-0.73)\end{array}$ \\
\hline Crisis $_{t} *$ Tightness $_{t} * \mathrm{RL}_{i, j, t}$ & & & $\begin{array}{l}0.028 \\
(0.89)\end{array}$ & $\begin{array}{l}0.030 \\
(0.94)\end{array}$ & $\begin{array}{l}0.030 \\
(0.97)\end{array}$ & & & $\begin{array}{l}0.483 \\
(0.91)\end{array}$ & $\begin{array}{l}0.577 \\
(1.02)\end{array}$ & $\begin{array}{l}0.550 \\
(0.98)\end{array}$ & $\begin{array}{l}0.784 \\
(1.34)\end{array}$ \\
\hline Total_trans_d $\mathrm{d}_{t} * \mathrm{RL}_{i, j, t}$ & & & & $\begin{array}{l}-0.005 \\
(-0.28)\end{array}$ & $\begin{array}{l}-0.006 \\
(-0.36)\end{array}$ & & & & $\begin{array}{l}-0.003 \\
(-0.06)\end{array}$ & $\begin{array}{l}0.007 \\
(0.12)\end{array}$ & $\begin{array}{l}0.046 \\
(0.75)\end{array}$ \\
\hline $\mathrm{Crisis}_{t} *$ Total_trans_d $\mathrm{d}_{t} * \mathrm{RL}_{i, j, t}$ & & & & $\begin{array}{l}-0.114^{*} \\
(-1.84)\end{array}$ & $\begin{array}{l}-0.111^{*} \\
(-1.80)\end{array}$ & & & & $\begin{array}{c}-2.901^{* *} \\
(-2.18)\end{array}$ & $\begin{array}{c}-2.951^{* *} \\
(-2.24)\end{array}$ & $\begin{array}{l}-2.476^{*} \\
(-1.81)\end{array}$ \\
\hline $\operatorname{Surplus}_{i, j, t}^{\text {len }}$ & & & & & $\begin{array}{l}-0.067 \\
(-0.98)\end{array}$ & & & & & $\begin{array}{l}0.494 \\
(0.90)\end{array}$ & $\begin{array}{l}0.772 \\
(1.38)\end{array}$ \\
\hline Surplus $_{i, j, t}^{b o r}$ & & & & & $\begin{array}{c}-0.323^{* * *} \\
(-3.50)\end{array}$ & & & & & $\begin{array}{l}-1.088 \\
(-1.05)\end{array}$ & $\begin{array}{l}-0.663 \\
(-0.59)\end{array}$ \\
\hline $\operatorname{Crisis}_{t} * \operatorname{Surplus}_{i, j, t}^{l e n}$ & & & & & $\begin{array}{l}-0.007 \\
(-0.07)\end{array}$ & & & & & $\begin{array}{l}-0.661 \\
(-0.43)\end{array}$ & $\begin{array}{l}-0.168 \\
(-0.09)\end{array}$ \\
\hline Crisis $_{t} *$ Surplus $_{i, j, t}^{b o r}$ & & & & & $\begin{array}{l}0.252^{*} \\
(1.83)\end{array}$ & & & & & $\begin{array}{c}5.316^{* * *} \\
(3.15)\end{array}$ & $\begin{array}{l}2.954^{*} \\
(1.97)\end{array}$ \\
\hline Corr_liq_shocks $s_{i, j, t}^{l e n}$ & & & & & $\begin{array}{l}0.014 \\
(0.86)\end{array}$ & & & & & $\begin{array}{l}-0.191^{*} \\
(-1.93)\end{array}$ & $\begin{array}{l}-0.168 \\
(-1.49)\end{array}$ \\
\hline $\operatorname{Crisis}_{t} *$ Corr_liq_shocks ${ }_{i, j, t}^{l e n}$ & & & & & $\begin{array}{l}0.034 \\
(0.74)\end{array}$ & & & & & $\begin{array}{l}0.385 \\
(0.41)\end{array}$ & $\begin{array}{l}0.229 \\
(0.27)\end{array}$ \\
\hline Inv_Mills_ratio $i, j, t$ & & & & & & $\begin{array}{c}-5.977^{* * *} \\
(-4.05)\end{array}$ & $\begin{array}{c}-4.961^{* * *} \\
(-3.72)\end{array}$ & $\begin{array}{c}-4.853^{* * *} \\
(-3.63)\end{array}$ & $\begin{array}{c}-4.336^{* * *} \\
(-3.30)\end{array}$ & $\begin{array}{c}-3.966^{* * *} \\
(-3.03)\end{array}$ & $\begin{array}{c}-2.638^{* *} \\
(-2.06)\end{array}$ \\
\hline Reciprocal_RL $\mathrm{R}_{i, j, t}$ & $\begin{array}{c}0.163^{* * *} \\
(8.19)\end{array}$ & $\begin{array}{c}0.162^{* * *} \\
(8.14)\end{array}$ & $\begin{array}{c}0.162^{* * *} \\
(8.12)\end{array}$ & $\begin{array}{c}0.162^{* * *} \\
(8.12)\end{array}$ & $\begin{array}{c}0.161^{* * *} \\
(8.05)\end{array}$ & $\begin{array}{c}-0.790^{* * *} \\
(-2.98)\end{array}$ & $\begin{array}{c}-0.691^{* * *} \\
(-2.82)\end{array}$ & $\begin{array}{c}-0.675^{* * *} \\
(-2.74)\end{array}$ & $\begin{array}{c}-0.617^{* *} \\
(-2.53)\end{array}$ & $\begin{array}{c}-0.538^{* *} \\
(-2.25)\end{array}$ & $\begin{array}{l}-0.253 \\
(-1.05)\end{array}$ \\
\hline No_formal_network $\mathrm{i}_{i, j}$ & $\begin{array}{c}-0.090^{* * *} \\
(-2.88)\end{array}$ & $\begin{array}{c}-0.090^{* * *} \\
(-2.88)\end{array}$ & $\begin{array}{c}-0.090^{* * *} \\
(-2.88)\end{array}$ & $\begin{array}{c}-0.089^{* * *} \\
(-2.88)\end{array}$ & $\begin{array}{c}-0.089^{* * *} \\
(-2.89)\end{array}$ & $\begin{array}{l}0.594 \\
(1.61)\end{array}$ & $\begin{array}{l}0.532 \\
(1.40)\end{array}$ & $\begin{array}{l}0.530 \\
(1.39)\end{array}$ & $\begin{array}{l}0.495 \\
(1.32)\end{array}$ & $\begin{array}{l}0.519 \\
(1.39)\end{array}$ & $\begin{array}{l}0.548 \\
(1.52)\end{array}$ \\
\hline Time-varying Borrower/Lender Col & Yes & Yes & Yes & Yes & Yes & Yes & Yes & $\mathrm{Ye}$ & Yes & Yes & Yes \\
\hline Day Fixed Effects & Yes & Yes & Yes & Yes & Yes & Ye: & Yes & Yes & Yes & Yes & Yes \\
\hline Lender Fixed Effects & Yes & Yes & Yes & Yes & Yes & Yes & Yes & Yes & Yes & Yes & Yes \\
\hline Borrower Fixed Effects & Yes & Yes & Yes & Yes & Yes & Yes & Yes & Yes & Yes & Yes & - \\
\hline Monthly Borrower Fixed Effects & No & No & No & No & No & No & No & No & No & No & Yes \\
\hline Observations & 447,785 & 447,785 & 447,785 & 447,785 & 447,785 & 15,857 & 15,857 & 15,857 & 15,857 & 15,857 & 15,857 \\
\hline
\end{tabular}

Notes: Estimated parameters of the bilateral matching models (dependent variable: Loan $_{i, j, t}$ ) and bilateral interest rate models (dependent variable: Spread ${ }_{i, j, t}$ ) corrected for sample selection bias (compare Section 3.2). Inverse mills ratio is based on full selection model depict in column (5). 'Time-varying Borrower/Lender Controls' refers to Assets, Equity, Excess_reserves, Centrality, Liquidity_Risk for both lender and borrower bank. Excess_reserves is excluded in the interest rate models. Fixed effects are included ('Yes'), not included ('No'), or spanned by another set of fixed effects ('-'). All models include a constant. We cluster robust standard errors at the borrower bank level and present robust t-statistics in parentheses; The symbols *, **, *** denote significance at the 10 percent, 5 percent, and 1 percent level. Table 9 summarizes the definition of all variables and Table 8 contains summary statistics. 
Table 5: Relationship Lending and Borrower Opacity.

\begin{tabular}{|c|c|c|c|c|c|c|c|c|c|c|c|c|c|c|}
\hline & \multicolumn{7}{|c|}{ Matching Probabilities: $P\left(\operatorname{Loan}_{i, j, t}=1\right)$} & \multicolumn{7}{|c|}{ Interest Rate Models: Spread $_{i, j, t}$} \\
\hline & $(1)$ & $(2)$ & $(3)$ & $(4)$ & $(5)$ & (6) & $(7)$ & $(8)$ & (9) & $(10)$ & $(11)$ & $(12)$ & $(13)$ & $(14)$ \\
\hline $\mathrm{RL}_{i, j, t}$ & $\begin{array}{c}0.763^{* * *} \\
(17.29)\end{array}$ & $\begin{array}{c}0.793^{* * *} \\
(24.27)\end{array}$ & $\begin{array}{c}0.668^{* * *} \\
(20.59)\end{array}$ & $\begin{array}{c}0.754^{* * *} \\
(18.11)\end{array}$ & $\begin{array}{c}0.776^{* * *} \\
(27.97)\end{array}$ & $\begin{array}{l}0.752^{* * *} \\
(13.24)\end{array}$ & $\begin{array}{c}1.203^{* * *} \\
(3.56)\end{array}$ & $\begin{array}{l}-1.379 \\
(-1.29)\end{array}$ & $\begin{array}{l}-2.891^{*} \\
(-2.04)\end{array}$ & $\begin{array}{l}-1.149 \\
(-1.05)\end{array}$ & $\begin{array}{l}-1.951^{*} \\
(-1.74)\end{array}$ & $\begin{array}{c}-2.279^{* *} \\
(-2.03)\end{array}$ & $\begin{array}{c}-3.143^{* * *} \\
(-3.55)\end{array}$ & $\begin{array}{c}-10.529^{* *} \\
(-2.27)\end{array}$ \\
\hline Split_rating $_{j, t}$ & $\begin{array}{l}0.007 \\
(0.11)\end{array}$ & & & & & & & $\begin{array}{c}1.756^{* * *} \\
(3.30)\end{array}$ & & & & & & \\
\hline $\mathrm{RL}_{i, j, t} *$ Split_rating ${ }_{j, t}$ & $\begin{array}{l}0.008 \\
(0.16)\end{array}$ & & & & & & & $\begin{array}{l}-0.546^{*} \\
(-1.95)\end{array}$ & & & & & & \\
\hline $\mathrm{CDS}_{-} \operatorname{vol}_{j, t}$ & & $\begin{array}{l}-0.064 \\
(-0.32)\end{array}$ & & & & & & & $\begin{array}{c}5.206^{* * *} \\
(3.11)\end{array}$ & & & & & \\
\hline $\mathrm{RL}_{i, j, t} * \mathrm{CDS} \_\operatorname{vol}_{j, t}$ & & $\begin{array}{l}-0.059 \\
(-0.71)\end{array}$ & & & & & & & $\begin{array}{c}-1.559^{* * *} \\
(-3.85)\end{array}$ & & & & & \\
\hline No_formal_network ${ }_{i, j}$ & & & $\begin{array}{l}-0.160^{* * *} \\
(-4.44)\end{array}$ & & & & & & & $\begin{array}{c}1.296^{* * *} \\
(2.95)\end{array}$ & & & & \\
\hline $\mathrm{RL}_{i, j, t} *$ No_formal_network $k_{i, j}$ & & & $\begin{array}{c}0.117^{* * *} \\
(3.04)\end{array}$ & & & & & & & $\begin{array}{c}-0.986^{* * *} \\
(-3.78)\end{array}$ & & & & \\
\hline Loans $_{j, t}$ & & & & $\begin{array}{l}0.087 \\
(0.19)\end{array}$ & & & & & & & & & & \\
\hline $\mathrm{RL}_{i, j, t} * \operatorname{Loans}_{j, t}$ & & & & $\begin{array}{l}0.057 \\
(0.51)\end{array}$ & & & & & & & $\begin{array}{c}-1.473^{* *} \\
(-2.37)\end{array}$ & & & \\
\hline $\operatorname{Cash}_{j, t}$ & & & & & $\begin{array}{c}67.799 \\
(1.48)\end{array}$ & & & & & & & & & \\
\hline $\mathrm{RL}_{i, j, t} * \operatorname{Cash}_{j, t}$ & & & & & $\begin{array}{l}-1.793 \\
(-0.19)\end{array}$ & & & & & & & $\begin{array}{c}-249.758^{*} \\
(-1.89)\end{array}$ & & \\
\hline Securities $_{j, t}$ & & & & & & $\begin{array}{l}0.544 \\
(1.31)\end{array}$ & & & & & & & & \\
\hline $\mathrm{RL}_{i, j, t} *$ Securities $_{j, t}$ & & & & & & $\begin{array}{l}0.090 \\
(0.48)\end{array}$ & & & & & & & $\begin{array}{l}2.370 \\
(1.55)\end{array}$ & \\
\hline $\operatorname{Debt}_{j, t}$ & & & & & & & $\begin{array}{c}0.784^{*} \\
(1.65)\end{array}$ & & & & & & & \\
\hline $\mathrm{RL}_{i, j, t} * \operatorname{Debt}_{j, t}$ & & & & & & & $\begin{array}{l}-0.483 \\
(-1.31)\end{array}$ & & & & & & & $\begin{array}{l}9.474 \\
(1.60)\end{array}$ \\
\hline Inv_Mills_ratio $i, j, t$ & & & & & & & & $\begin{array}{l}-2.394 \\
(-1.49)\end{array}$ & $\begin{array}{l}-4.572^{*} \\
(-1.90)\end{array}$ & $\begin{array}{l}-3.037 \\
(-1.57)\end{array}$ & $\begin{array}{c}-3.705^{* *} \\
(-2.21)\end{array}$ & $\begin{array}{c}-3.744^{* *} \\
(-2.18)\end{array}$ & $\begin{array}{c}-3.933^{* *} \\
(-2.46)\end{array}$ & $\begin{array}{l}-3.212 \\
(-1.60)\end{array}$ \\
\hline Time-varying Pair Controls & Yes & Yes & Yes & Yes & Yes & Yes & Yes & Yes & Yes & Yes & Yes & Yes & Yes & Yes \\
\hline Day Fixed Effects & Yes & Yes & Yes & Yes & Yes & Yes & Yes & Yes & Yes & Yes & Yes & Yes & Yes & Yes \\
\hline Lender Fixed Effects & Yes & Yes & Yes & Yes & Yes & Yes & Yes & Yes & Yes & Yes & Yes & Yes & Yes & Yes \\
\hline Borrower Fixed Effects & Yes & Yes & Yes & Yes & Yes & Yes & Yes & - & - & - & - & - & - & - \\
\hline Monthly Borrower Fixed Effects & No & No & No & No & No & No & No & Yes & Yes & Yes & Yes & Yes & Yes & Yes \\
\hline Observations & 318,067 & 205,840 & 447,785 & 447,785 & 447,785 & 447,785 & 447,785 & 12,117 & 9,796 & 15,857 & 15,857 & 15,857 & 15,857 & 15,857 \\
\hline
\end{tabular}

Notes: Estimated parameters of the bilateral matching models (dependent variable: Loan $_{i, j, t}$ ) and bilateral interest rate models $\left(\right.$ dependent variable: $S_{p r e a d_{i, j, t}}$ ) corrected for sample selection bias (compare Section 3.2). Inverse Mills ratios in model (8), [(9),(10),...] are based on corresponding matching models in column (1), [(2),(3),...]. 'Time-varying Pair Controls' refers to Assets, Equity, Excess reserves, Centrality, Liquidity Risk for both lender and borrower bank and Reverse_RL. Excess_reserves is excluded in the interest rate models. Fixed effects are included ('Yes'), not included ('No'), or spanned by another set of fixed effects ('-'). All models include a constant. We cluster robust standard errors at the borrower bank level and present robust t-statistics in parentheses; The symbols $*, * *, * * *$ denote significance at the 10 percent, 5 percent, and 1 percent level. Table 9 summarizes the definition of all variables and Table 8 contains summary statistics. 
Table 6: Relationship Lending and Aggregate Market Conditions (Robustness with $\mathrm{LPI}_{i, j, t} / \mathrm{BPI}_{i, j, t}$ ).

\begin{tabular}{|c|c|c|c|c|c|c|c|c|c|}
\hline & \multicolumn{4}{|c|}{ Matching Probabilities: $P\left(\operatorname{Loan}_{i, j, t}=1\right)$} & \multicolumn{5}{|c|}{ Interest Rate Models: Spread $_{i, j, t}$} \\
\hline & (1) & (2) & (3) & (4) & (5) & (6) & (7) & (8) & (9) \\
\hline $\mathrm{LPI}_{i, j, t}$ & $\begin{array}{c}1.513^{* * *} \\
(18.50)\end{array}$ & $\begin{array}{c}1.537^{* * *} \\
(17.57)\end{array}$ & $\begin{array}{c}1.562^{* * *} \\
(17.11)\end{array}$ & $\begin{array}{c}1.483^{* * *} \\
(16.04)\end{array}$ & $\begin{array}{l}-1.258 \\
(-0.81)\end{array}$ & $\begin{array}{l}-0.252 \\
(-0.16)\end{array}$ & $\begin{array}{l}-0.757 \\
(-0.47)\end{array}$ & $\begin{array}{l}-2.363 \\
(-1.35)\end{array}$ & $\begin{array}{l}-0.427 \\
(-0.19)\end{array}$ \\
\hline Crisis $_{t} * \operatorname{LPI}_{i, j, t}$ & & $\begin{array}{l}-0.137 \\
(-1.45)\end{array}$ & $\begin{array}{l}-0.154 \\
(-1.59)\end{array}$ & $\begin{array}{c}-0.266^{* * *} \\
(-3.00)\end{array}$ & & $\begin{array}{c}-2.651^{* * *} \\
(-4.15)\end{array}$ & $\begin{array}{c}-2.236^{* *} \\
(-2.62)\end{array}$ & $\begin{array}{l}-1.518^{*} \\
(-1.87)\end{array}$ & $\begin{array}{l}-0.750 \\
(-0.73)\end{array}$ \\
\hline Tightness $_{t} * \operatorname{LPI}_{i, j, t}$ & & & $\begin{array}{c}-0.122^{* *} \\
(-2.48)\end{array}$ & $\begin{array}{c}-0.135^{* * *} \\
(-2.63)\end{array}$ & & & $\begin{array}{l}0.117 \\
(0.53)\end{array}$ & $\begin{array}{l}0.264 \\
(0.97)\end{array}$ & $\begin{array}{l}0.121 \\
(0.34)\end{array}$ \\
\hline Crisis $_{t} *$ Tightness $_{t} * \mathrm{LPI}_{i, j, t}$ & & & $\begin{array}{l}0.102 \\
(1.06)\end{array}$ & $\begin{array}{l}0.066 \\
(0.65)\end{array}$ & & & $\begin{array}{l}-0.548 \\
(-0.36)\end{array}$ & $\begin{array}{l}-0.473 \\
(-0.30)\end{array}$ & $\begin{array}{l}-0.474 \\
(-0.31)\end{array}$ \\
\hline Total_trans_d $\mathrm{d}_{t} * \mathrm{LPI}_{i, j, t}$ & & & $\begin{array}{l}-0.025 \\
(-0.59)\end{array}$ & $\begin{array}{l}-0.006 \\
(-0.14)\end{array}$ & & & $\begin{array}{l}0.304^{*} \\
(1.83)\end{array}$ & $\begin{array}{l}0.269 \\
(1.55)\end{array}$ & $\begin{array}{c}0.380^{* *} \\
(2.29)\end{array}$ \\
\hline Crisis $_{t} *$ Total_trans_d ${ }_{t} * \mathrm{LPI}_{i, j, t}$ & & & $\begin{array}{l}0.020 \\
(0.12)\end{array}$ & $\begin{array}{l}-0.029 \\
(-0.17)\end{array}$ & & & $\begin{array}{l}-6.594 \\
(-1.63)\end{array}$ & $\begin{array}{l}-6.441 \\
(-1.60)\end{array}$ & $\begin{array}{l}-5.353 \\
(-1.28)\end{array}$ \\
\hline $\mathrm{BPI}_{i, j, t}$ & $\begin{array}{c}0.913^{* * *} \\
(8.49)\end{array}$ & $\begin{array}{c}0.900^{* * *} \\
(7.96)\end{array}$ & $\begin{array}{c}0.900^{* * *} \\
(8.21)\end{array}$ & $\begin{array}{c}0.852^{* * *} \\
(7.58)\end{array}$ & $\begin{array}{l}-1.231 \\
(-1.23)\end{array}$ & $\begin{array}{l}-1.728^{*} \\
(-1.82)\end{array}$ & $\begin{array}{l}-1.742^{*} \\
(-1.79)\end{array}$ & $\begin{array}{c}-2.619^{* *} \\
(-2.42)\end{array}$ & $\begin{array}{l}-1.531 \\
(-1.14)\end{array}$ \\
\hline $\operatorname{Crisis}_{t} * \mathrm{BPI}_{i, j, t}$ & & $\begin{array}{l}0.056 \\
(0.55)\end{array}$ & $\begin{array}{l}-0.009 \\
(-0.09)\end{array}$ & $\begin{array}{l}-0.046 \\
(-0.42)\end{array}$ & & $\begin{array}{l}3.356^{*} \\
(1.83)\end{array}$ & $\begin{array}{l}4.221^{*} \\
(1.91)\end{array}$ & $\begin{array}{l}3.865^{*} \\
(1.76)\end{array}$ & $\begin{array}{l}2.487 \\
(1.11)\end{array}$ \\
\hline Tightness $_{t} * \mathrm{BPI}_{i, j, t}$ & & & $\begin{array}{l}-0.015 \\
(-0.25)\end{array}$ & $\begin{array}{l}-0.017 \\
(-0.28)\end{array}$ & & & $\begin{array}{c}-0.705^{* *} \\
(-2.30)\end{array}$ & $\begin{array}{c}-0.686^{* *} \\
(-2.26)\end{array}$ & $\begin{array}{l}-0.910^{* *} \\
(-2.34)\end{array}$ \\
\hline Crisis $_{t} *$ Tightness $_{t} * \mathrm{BPI}_{i, j, t}$ & & & $\begin{array}{c}0.299^{* * *} \\
(2.85)\end{array}$ & $\begin{array}{c}0.307^{* * *} \\
(2.89)\end{array}$ & & & $\begin{array}{l}-3.129 \\
(-1.66)\end{array}$ & $\begin{array}{l}-3.662^{*} \\
(-1.95)\end{array}$ & $\begin{array}{l}-3.412^{*} \\
(-1.76)\end{array}$ \\
\hline Total_trans_d $\mathrm{d}_{t} * \mathrm{BPI}_{i, j, t}$ & & & $\begin{array}{l}0.006 \\
(0.07)\end{array}$ & $\begin{array}{l}0.005 \\
(0.06)\end{array}$ & & & $\begin{array}{c}-0.746^{* * *} \\
(-2.93)\end{array}$ & $\begin{array}{c}-0.757^{* * *} \\
(-3.10)\end{array}$ & $\begin{array}{c}-0.812^{* * *} \\
(-4.45)\end{array}$ \\
\hline Crisis $t_{t} *$ Total_trans_d $\mathrm{d}_{t} * \mathrm{BPI}_{i, j, t}$ & & & $\begin{array}{c}-0.613^{* * *} \\
(-2.71)\end{array}$ & $\begin{array}{c}-0.620^{* * *} \\
(-2.62)\end{array}$ & & & $\begin{array}{l}3.975 \\
(0.92)\end{array}$ & $\begin{array}{l}4.602 \\
(1.09)\end{array}$ & $\begin{array}{l}5.032 \\
(1.18)\end{array}$ \\
\hline Surplus ${ }_{i, j, t}^{l e n}$ & & & & $\begin{array}{c}0.485^{* * *} \\
(8.09)\end{array}$ & & & & $\begin{array}{l}-0.624 \\
(-0.68)\end{array}$ & $\begin{array}{l}0.363 \\
(0.36)\end{array}$ \\
\hline Surplus $_{i, j, t}^{\text {bor }}$ & & & & $\begin{array}{c}0.672^{* * *} \\
(6.26)\end{array}$ & & & & $\begin{array}{c}-2.773^{* * *} \\
(-2.78)\end{array}$ & $\begin{array}{l}-1.556^{*} \\
(-1.70)\end{array}$ \\
\hline Crisis $_{t} *$ Surplus len $_{i, j, t}^{l e n}$ & & & & $\begin{array}{c}0.194^{* *} \\
(1.98)\end{array}$ & & & & $\begin{array}{l}-1.763 \\
(-1.16)\end{array}$ & $\begin{array}{l}-1.746 \\
(-0.96)\end{array}$ \\
\hline Crisis $_{t} *$ Surplus $_{i, j, t}^{b o r}$ & & & & $\begin{array}{l}-0.062 \\
(-0.41)\end{array}$ & & & & $\begin{array}{c}4.367^{* *} \\
(2.51)\end{array}$ & $\begin{array}{l}2.327 \\
(1.46)\end{array}$ \\
\hline Corr_liq_shocks $\mathrm{len}_{i, j, t}^{\mathrm{len}}$ & & & & $\begin{array}{l}0.047^{*} \\
(1.66)\end{array}$ & & & & $\begin{array}{c}-0.229^{* *} \\
(-2.26)\end{array}$ & $\begin{array}{l}-0.175 \\
(-1.21)\end{array}$ \\
\hline Crisis $_{t} *$ Corr_liq_shocks len & & & & $\begin{array}{l}-0.012 \\
(-0.21)\end{array}$ & & & & $\begin{array}{l}0.683 \\
(0.66)\end{array}$ & $\begin{array}{l}0.402 \\
(0.44)\end{array}$ \\
\hline Inv_Mills_ratio $i, j, t$ & & & & & $\begin{array}{l}-1.300 \\
(-1.14)\end{array}$ & $\begin{array}{l}-0.905 \\
(-0.78)\end{array}$ & $\begin{array}{l}-1.278 \\
(-1.11)\end{array}$ & $\begin{array}{l}-2.673^{*} \\
(-1.86)\end{array}$ & $\begin{array}{l}-0.962 \\
(-0.52)\end{array}$ \\
\hline No_formal_network $i, j$ & $\begin{array}{l}-0.057 \\
(-1.03) \\
\end{array}$ & $\begin{array}{l}-0.057 \\
(-1.03) \\
\end{array}$ & $\begin{array}{l}-0.057 \\
(-1.04) \\
\end{array}$ & $\begin{array}{l}-0.057 \\
(-1.06) \\
\end{array}$ & $\begin{array}{l}0.263 \\
(0.79) \\
\end{array}$ & $\begin{array}{l}0.229 \\
(0.69) \\
\end{array}$ & $\begin{array}{l}0.259 \\
(0.78) \\
\end{array}$ & $\begin{array}{l}0.356 \\
(0.99) \\
\end{array}$ & $\begin{array}{l}0.390 \\
(1.07) \\
\end{array}$ \\
\hline Time-varying Borrower/Lender Controls & Yes & Yes & Yes & Yes & Yes & Yes & Yes & Yes & Yes \\
\hline Day Fixed Effects & Yes & Yes & Yes & Yes & Yes & Yes & Yes & Yes & Yes \\
\hline Lender Fixed Effects & Yes & Yes & Yes & Yes & Yes & Yes & Yes & Yes & Yes \\
\hline Borrower Fixed Effects & Yes & Yes & Yes & Yes & Yes & Yes & Yes & Yes & - \\
\hline Monthly Borrower Fixed Effects & No & No & No & No & No & No & No & No & Yes \\
\hline Observations & 447,785 & 447,785 & 447,785 & 447,785 & 15,857 & 15,857 & 15,857 & 15,857 & 15,857 \\
\hline
\end{tabular}

Notes: Estimated parameters of the bilateral matching models (dependent variable: Loan $_{i, j, t}$ ) and bilateral interest rate models (dependent variable: Spread $_{i, j, t}$ ) corrected for sample selection bias (compare Section 3.2). Inverse Mills ratio is based on full selection model depict in column (4). 'Time-varying Borrower/Lender Controls' refers to Assets, Equity, Excess_reserves, Centrality, Liquidity_Risk for both lender and borrower bank. Excess_reserves is excluded in the interest rate models. Fixed effects are included ('Yes'), not included ('No'), or spanned by another set of fixed effects ('-'). All models include a constant. We cluster robust standard errors at the borrower bank level and present robust t-statistics in parentheses; The symbols *, **, *** denote significance at the 10 percent, 5 percent, and 1 percent level. Table 9 summarizes the definition of all variables and Table 8 contains summary statistics. 
Table 7: Relationship Lending and Borrower Opacity (Robustness with $\mathrm{LPI}_{i, j, t} / \mathrm{BPI}_{i, j, t}$ ).

\begin{tabular}{|c|c|c|c|c|c|c|c|c|c|c|c|c|c|c|}
\hline & \multicolumn{7}{|c|}{ Matching Probabilities: $P\left(\operatorname{Loan}_{i, j, t}=1\right)$} & \multicolumn{7}{|c|}{ Interest Rate Models: Spread $_{i, j, t}$} \\
\hline & (1) & (2) & (3) & (4) & $(5)$ & $(6)$ & (7) & (8) & (9) & (10) & (11) & (12) & (13) & (14) \\
\hline $\mathrm{LPI}_{i, j, t}$ & $\begin{array}{c}1.288^{* * *} \\
(10.92)\end{array}$ & $\begin{array}{r}1.521^{* * *} \\
(15.21)\end{array}$ & $\begin{array}{c}1.112^{* * *} \\
(8.32)\end{array}$ & $\begin{array}{c}1.470^{* * *} \\
(8.69)\end{array}$ & $\begin{array}{c}1.480^{* * *} \\
(16.89)\end{array}$ & $\begin{array}{c}1.589^{* * *} \\
(8.99)\end{array}$ & $\begin{array}{c}4.100^{* * *} \\
(3.26)\end{array}$ & $\begin{array}{l}1.994 \\
(0.61)\end{array}$ & $\begin{array}{l}-0.436 \\
(-0.14)\end{array}$ & $\begin{array}{l}0.205 \\
(0.10)\end{array}$ & $\begin{array}{l}0.767 \\
(0.20)\end{array}$ & $\begin{array}{l}-0.819 \\
(-0.26)\end{array}$ & $\begin{array}{l}-3.277 \\
(-1.55)\end{array}$ & $\begin{array}{r}-16.610^{*} \\
(-1.72)\end{array}$ \\
\hline $\mathrm{BPI}_{i, j, t}$ & $\begin{array}{c}0.901^{* * *} \\
(4.60)\end{array}$ & $\begin{array}{c}1.660^{* * *} \\
(5.03)\end{array}$ & $\begin{array}{c}1.046^{* * *} \\
(4.77)\end{array}$ & $\begin{array}{c}0.883^{* * *} \\
(4.99)\end{array}$ & $\begin{array}{c}0.979^{* * *} \\
(8.06)\end{array}$ & $\begin{array}{c}1.106^{* * *} \\
(4.69)\end{array}$ & $\begin{array}{l}-0.592 \\
(-0.64)\end{array}$ & $\begin{array}{l}-2.050 \\
(-1.34)\end{array}$ & $\begin{array}{l}-2.544 \\
(-0.90)\end{array}$ & $\begin{array}{l}0.626 \\
(0.30)\end{array}$ & $\begin{array}{l}-0.459 \\
(-0.28)\end{array}$ & $\begin{array}{l}-1.789 \\
(-1.06)\end{array}$ & $\begin{array}{l}-2.080 \\
(-0.83)\end{array}$ & $\begin{array}{l}6.550 \\
(0.58)\end{array}$ \\
\hline Split_rating $j, t$ & $\begin{array}{l}-0.040 \\
(-0.48)\end{array}$ & & & & & & & $\begin{array}{c}1.562^{* * *} \\
(3.14)\end{array}$ & & & & & & \\
\hline $\operatorname{LPI}_{i, j, t} *$ Split_rating $j, t$ & $\begin{array}{l}0.227 \\
(1.51)\end{array}$ & & & & & & & $\begin{array}{l}-2.536^{* *} \\
(-2.45)\end{array}$ & & & & & & \\
\hline $\mathrm{BPI}_{i, j, t} *$ Split_rating $_{j, t}$ & $\begin{array}{l}0.238 \\
(0.91)\end{array}$ & & & & & & & $\begin{array}{l}-0.063 \\
(-0.05)\end{array}$ & & & & & & \\
\hline CDS_vol ${ }_{j, t}$ & & $\begin{array}{l}-0.036 \\
(-0.18)\end{array}$ & & & & & & & $\begin{array}{l}3.761^{* *} \\
(2.46)\end{array}$ & & & & & \\
\hline $\mathrm{LPI}_{i, j, t} * \mathrm{CDS} \_\mathrm{vol}_{j, t}$ & & $\begin{array}{l}-0.086 \\
(-0.27)\end{array}$ & & & & & & & $\begin{array}{l}-4.635^{*} \\
(-2.09)\end{array}$ & & & & & \\
\hline $\mathrm{BPI}_{i, j, t} *$ CDS_vol $j, t$ & & $\begin{array}{c}-0.857^{* *} \\
(-2.39)\end{array}$ & & & & & & & $\begin{array}{l}1.330 \\
(0.49)\end{array}$ & & & & & \\
\hline No_formal_network ${ }_{i, j}$ & & & $\begin{array}{r}-0.110^{*} \\
(-1.91)\end{array}$ & & & & & & & $\begin{array}{c}0.729^{*} \\
(1.86)\end{array}$ & & & & \\
\hline $\mathrm{LPI}_{i, j, t} *$ No_formal_network ${ }_{i, j}$ & & & $\begin{array}{c}0.467^{* * *} \\
(3.14)\end{array}$ & & & & & & & $\begin{array}{l}-0.770 \\
(-0.73)\end{array}$ & & & & \\
\hline $\mathrm{BPI}_{i, j, t} *$ No_formal_network ${ }_{i, j}$ & & & $\begin{array}{l}-0.150 \\
(-0.70)\end{array}$ & & & & & & & $\begin{array}{l}-2.368^{*} \\
(-1.84)\end{array}$ & & & & \\
\hline Loans $_{j, t}$ & & & & $\begin{array}{l}0.057 \\
(0.09)\end{array}$ & & & & & & & & & & \\
\hline $\operatorname{LPI}_{i, j, t} *$ Loans $_{j, t}$ & & & & $\begin{array}{l}0.128 \\
(0.31)\end{array}$ & & & & & & & $\begin{array}{l}-3.810 \\
(-1.13)\end{array}$ & & & \\
\hline $\mathrm{BPI}_{i, j, t} *$ Loans $_{j, t}$ & & & & $\begin{array}{l}0.088 \\
(0.19)\end{array}$ & & & & & & & $\begin{array}{l}-3.201 \\
(-1.09)\end{array}$ & & & \\
\hline $\operatorname{Cash}_{j, t}$ & & & & & $\begin{array}{l}52.866 \\
(1.15)\end{array}$ & & & & & & & & & \\
\hline $\mathrm{LPI}_{i, j, t} * \mathrm{Cash}_{j, t}$ & & & & & $\begin{array}{c}38.349 \\
(0.80)\end{array}$ & & & & & & & $\begin{array}{c}-122.363 \\
(-0.38)\end{array}$ & & \\
\hline $\mathrm{BPI}_{i, j, t} * \mathrm{Cash}_{j, t}$ & & & & & $\begin{array}{l}-59.985^{* * *} \\
(-2.61)\end{array}$ & & & & & & & $\begin{array}{l}54.289 \\
(0.26)\end{array}$ & & \\
\hline Securities $_{j, t}$ & & & & & & $\begin{array}{l}0.994 \\
(1.37)\end{array}$ & & & & & & & & \\
\hline $\operatorname{LPI}_{i, j, t} *$ Securities $_{j, t}$ & & & & & & $\begin{array}{l}-0.343 \\
(-0.55)\end{array}$ & & & & & & & $\begin{array}{c}10.032 \\
(1.53)\end{array}$ & \\
\hline $\operatorname{BPI}_{i, j, t} *$ Securities $_{j, t}$ & & & & & & $\begin{array}{l}-0.773 \\
(-1.06)\end{array}$ & & & & & & & $\begin{array}{l}0.822 \\
(0.18)\end{array}$ & \\
\hline Debt $_{j, t}$ & & & & & & & $\begin{array}{l}1.339^{*} \\
(1.73)\end{array}$ & & & & & & & \\
\hline $\operatorname{LPI}_{i, j, t} * \operatorname{Debt}_{j, t}$ & & & & & & & $\begin{array}{c}-2.916^{* *} \\
(-2.06)\end{array}$ & & & & & & & $\begin{array}{l}17.462 \\
(1.55)\end{array}$ \\
\hline $\mathrm{BPI}_{i, j, t} * \operatorname{Debt}_{j, t}$ & & & & & & & $\begin{array}{l}1.701^{*} \\
(1.68) \\
\end{array}$ & & & & & & & $\begin{array}{l}-9.412 \\
(-0.75) \\
\end{array}$ \\
\hline Time-varying Pair Controls & Yes & Yes & Yes & Yes & Yes & Yes & Yes & Yes & Yes & Yes & Yes & Yes & Yes & Yes \\
\hline Day Fixed Effects & Yes & Yes & Yes & Yes & Yes & Yes & Yes & Yes & Yes & Yes & Yes & Yes & Yes & Yes \\
\hline Lender Fixed Effects & Yes & Yes & Yes & Yes & Yes & Yes & Yes & Yes & Yes & Yes & Yes & Yes & Yes & Yes \\
\hline Borrower Fixed Effects & Yes & Yes & Yes & Yes & Yes & Yes & Yes & - & - & - & - & - & - & - \\
\hline Monthly Bor. Fixed Effects & No & No & No & No & No & No & No & Yes & Yes & Yes & Yes & Yes & Yes & Yes \\
\hline Observations & 318,067 & 205,840 & 447,785 & 447,785 & 447,785 & 447,785 & 447,785 & 12,117 & 9,796 & 15,857 & 15,857 & 15,857 & 15,857 & 15,857 \\
\hline
\end{tabular}

Notes: Estimated parameters of the bilateral matching models (dependent variable: $\operatorname{Loan}_{i, j, t}$ ) and bilateral interest rate models (dependent variable: Spread $_{i, j, t}$ ) corrected for sample selection bias (compare Section 3.2). Inverse Mills ratios in model $(8),[(9),(10), \ldots]$ are based on corresponding matching models in column $(1),[(2),(3), \ldots]$. 'Time-varying Pair Controls' refers to Assets, Equity, Excess_reserves, Centrality, Liquidity_Risk for both lender and borrower bank and Reverse_RL. Excess_reserves is excluded in the interest rate models. Fixed effects are included ('Yes'), not included ('No'), or spanned by another set of fixed effects ('-'). All models include a constant. We cluster robust standard errors at the borrower bank level and present robust t-statistics in parentheses; The symbols *, **, *** denote significance at the 10 percent, 5 percent, and 1 percent level. Table 9 summarizes the definition of all variables and Table 8 contains summary statistics. 
Table 8: Summary Statistics of Variables.

\begin{tabular}{|c|c|c|c|c|c|}
\hline Variable & Mean & $\begin{array}{l}\text { Standard } \\
\text { Deviation }\end{array}$ & $\begin{array}{c}5 \text { th } \\
\text { Percentile }\end{array}$ & $\begin{array}{c}95 \text { th } \\
\text { Percentile }\end{array}$ & Observations \\
\hline \multicolumn{6}{|c|}{ Pair-Specific Characteristics } \\
\hline $\operatorname{Loan}_{i, j, t}$ & 0.035 & 0.185 & 0.000 & 0.000 & 447,785 \\
\hline Spread $_{i, j, t}$ & 8.592 & 15.944 & -15.415 & 35.972 & 15,857 \\
\hline $\mathrm{RL}_{i, j, t}$ & 0.284 & 0.580 & 0.000 & 1.609 & 447,785 \\
\hline Reciprocal_ $\mathrm{RL}_{i, j, t}$ & 0.126 & 0.384 & 0.000 & 1.099 & 447,785 \\
\hline $\mathrm{LPI}_{i, j, t}$ & 0.064 & 0.175 & 0.000 & 0.430 & 447,785 \\
\hline $\mathrm{BPI}_{i, j, t}$ & 0.043 & 0.149 & 0.000 & 0.248 & 447,785 \\
\hline Surplus $_{i, j, t}^{l e n}$ & 0.034 & 0.110 & 0.000 & 0.200 & 447,785 \\
\hline Surplus ${ }_{i, j, t}^{b o r}$ & 0.021 & 0.077 & 0.000 & 0.118 & 447,785 \\
\hline Corr_liq_shocks $s_{i, j, t}$ & 0.024 & 0.266 & -0.407 & 0.476 & 447,785 \\
\hline No_formal_network $_{i, j}$ & 0.854 & 0.353 & 0.000 & 1.000 & 1,079 \\
\hline \multicolumn{6}{|c|}{ Lender-Specific Characteristics } \\
\hline Assets $_{i, t}$ & 9.328 & 2.275 & 5.524 & 12.566 & 1,520 \\
\hline Equity $_{i, t}$ & 0.056 & 0.064 & 0.010 & 0.128 & 1,520 \\
\hline Excess_reserves $_{i, t}$ & 0.229 & 1.842 & -0.937 & 1.683 & 31,540 \\
\hline Centrality $_{i, t}$ & 0.483 & 0.891 & 0.000 & 2.148 & 31,540 \\
\hline Liquidity_risk ${ }_{i, t}$ & 0.034 & 0.041 & 0.008 & 0.076 & 31,540 \\
\hline \multicolumn{6}{|c|}{ Borrower-Specific Characteristics } \\
\hline $\operatorname{Assets}_{j, t}$ & 9.688 & 2.131 & 5.794 & 12.678 & 1,320 \\
\hline Equity $_{j, t}$ & 0.049 & 0.057 & 0.010 & 0.113 & 1,320 \\
\hline Loans $_{j, t}$ & 0.363 & 0.202 & 0.030 & 0.645 & 1,320 \\
\hline $\operatorname{Cash}_{j, t}$ & 0.001 & 0.002 & 0.000 & 0.006 & 1,320 \\
\hline Securities $_{j, t}$ & 0.239 & 0.143 & 0.010 & 0.481 & 1,320 \\
\hline $\operatorname{Debt}_{j, t}$ & 0.874 & 0.106 & 0.751 & 0.957 & 1,320 \\
\hline Excess_reserves $_{j, t}$ & 0.170 & 1.180 & -0.938 & 1.593 & 27,390 \\
\hline Centrality $_{j, t}$ & 0.447 & 0.991 & 0.000 & 2.723 & 27,390 \\
\hline Liquidity_risk $_{j, t}$ & 0.031 & 0.026 & 0.009 & 0.068 & 27,390 \\
\hline $\mathrm{CDS}_{-} \mathrm{vol}_{j, t}$ & 0.090 & 0.122 & 0.003 & 0.319 & 6,225 \\
\hline Split_rating $_{j, t}$ & 0.638 & 0.481 & 0.000 & 1.000 & 16,244 \\
\hline \multicolumn{6}{|c|}{ Aggregate Market Conditions } \\
\hline Crisis $_{t}$ & 0.171 & 0.377 & 0.000 & 1.000 & 415 \\
\hline Total_trans ${ }_{t}$ & 43.325 & 11.899 & 26.000 & 65.000 & 415 \\
\hline Total_trans_d $\mathrm{d}_{t}$ & 0.202 & 0.402 & 0.000 & 1.000 & 415 \\
\hline Market_tight $t$ & 1.508 & 0.233 & 1.148 & 1.900 & 415 \\
\hline Tightness $_{t}$ & 0.178 & 0.383 & 0.000 & 1.000 & 415 \\
\hline
\end{tabular}

Notes: Summary statistics of variables used in the empirical analysis. The number of observations depends on the unit of observation of the respective variable. The dataset covers the period from March 1, 2006 to November 15 , 2007. Table 9 summarizes the definition of all variables. 
Table 9: Definition of Variables

\begin{tabular}{|c|c|}
\hline Variable & Definition \\
\hline \multicolumn{2}{|r|}{ Pair-Specific Variables } \\
\hline $\operatorname{Loan}_{i, j, t}$ & $\begin{array}{l}\text { Dummy variable that equals one if lender } i \text { grants an overnight interbank loan to borrower } \\
j \text { at day } t \text {, and zero otherwise }\end{array}$ \\
\hline $\operatorname{Spread}_{i, j, t}$ & $\begin{array}{l}\text { Difference between overnight interest rate negotiated by lender } i \text { and borrower } j \text { at day } \\
t \text { and the ECB minimum bid rate at the main refinancing operations (in percentage per } \\
\text { annum) }\end{array}$ \\
\hline $\mathrm{RL}_{i, j, t}$ & $\begin{array}{l}\text { Logarithm of }(1+\text { the number of loans granted from lender } i \text { to borrower } j \text { during the last } \\
30 \text { days preceding day } t)\end{array}$ \\
\hline $\mathrm{LPI}_{i, j, t}$ & $\begin{array}{l}\text { Amount lent by lender } i \text { to borrower } j \text { during the last } 30 \text { days preceding day } t \text { divided by } \\
\text { overall amount lent by bank } i \text { during the last } 30 \text { days preceding day } t\end{array}$ \\
\hline $\mathrm{BPI}_{i, j, t}$ & $\begin{array}{l}\text { Amount borrowed by borrower } j \text { from lender } i \text { during the last } 30 \text { days preceding day } t \\
\text { divided by total borrowing of bank } j \text { during the last } 30 \text { days preceding day } t\end{array}$ \\
\hline Reciprocal_RL $\mathrm{L}_{i, j, t}$ & $\begin{array}{l}\text { Logarithm of }(1+\text { the number of loans granted from borrower } j \text { to lender } j \text { during the last } \\
30 \text { days preceding day } t)\end{array}$ \\
\hline Lender_surplus $_{i, j, t}$ & $\begin{array}{l}\text { Realized (normalized) surplus compared with other loans of lender } i \text { when lending to } \\
\text { borrower } j \text { during the last } 30 \text { days preceding day } t \text { (in percentage per annum) }\end{array}$ \\
\hline Borrower_surplus $s_{i, j, t}$ & $\begin{array}{l}\text { Realized (normalized) surplus compared with other loans of borrower } j \text { when borrowing } \\
\text { from lender } i \text { during the last } 30 \text { days preceding day } t \text { (in percentage per annum) }\end{array}$ \\
\hline Corr_liq_shocks ${ }_{i, j, t}$ & $\begin{array}{l}\text { Correlation of daily changes in reserve holdings of lender } i \text { and borrower } j \text { during the last } \\
30 \text { days preceding day } t\end{array}$ \\
\hline \multicolumn{2}{|r|}{ Bank-Specific Variables } \\
\hline Assets $_{i, t}$ & $\begin{array}{l}\text { Logarithm of total assets (in EUR millions) according to balance sheet record of month } \\
\text { preceding day } t\end{array}$ \\
\hline Equity $_{i, t}$ & $\begin{array}{l}\text { Fraction of equity over total assets according to balance sheet record of month preceding } \\
\text { day } t\end{array}$ \\
\hline Loans $_{i, t}$ & $\begin{array}{l}\text { Fraction of loans to corporates over total assets according to balance sheet record of month } \\
\text { preceding day } t\end{array}$ \\
\hline $\operatorname{Cash}_{i, t}$ & $\begin{array}{l}\text { Fraction of cash holdings over total assets according to balance sheet record of month } \\
\text { preceding day } t\end{array}$ \\
\hline Securities $_{i, t}$ & $\begin{array}{l}\text { Fraction of securities holding over total assets according to balance sheet record of month } \\
\text { preceding day } t\end{array}$ \\
\hline Debt $_{i, t}$ & $\begin{array}{l}\text { Fraction of debt instruments over total liabilities according to balance sheet record of month } \\
\text { preceding day } t\end{array}$ \\
\hline Liq_risk $_{i, t}$ & $\begin{array}{l}\text { Standard deviation of daily change in reserve holdings during the last } 30 \text { days preceding } \\
\text { day } t \text { divided by reserve requirements }\end{array}$ \\
\hline Excess_reserves $_{i, t}$ & $\begin{array}{l}\text { Actual reserve holding at day } t \text { minus the amount a bank needs to hold on a daily basis for } \\
\text { the balance of the reserve maintenance period in order to exactly fulfill reserve requirements, } \\
\text { divided by the average daily required reserves }\end{array}$ \\
\hline Centrality $_{i, t}$ & $\begin{array}{l}\text { Bonacich centrality measure: Total interbank lending/borrowing during the last } 30 \text { days } \\
\text { preceding day } t \text { scaled s.t. } \sum_{k} \text { centrality equal total number of lenders/borrowers at } t\end{array}$ \\
\hline $\mathrm{CDS}_{-} \operatorname{vol}_{i, t}$ & $\begin{array}{l}\text { Coefficient of variation of the } 5 \text {-year CDS spread of bank } i \text { during the last } 30 \text { days preceding } \\
\text { day } t\end{array}$ \\
\hline Split_rating $_{i, t}$ & $\begin{array}{l}\text { Dummy variable that equals one if at time } t \text { the three major rating agencies disagree on } \\
\text { the credit quality of bank } i \text {, and is zero otherwise } \\
\text { Market-Wide Variables }\end{array}$ \\
\hline Market_tight ${ }_{t}$ & Number of lenders divided by number of borro \\
\hline Tightness $_{t}$ & $\begin{array}{l}\text { Dummy variable that equals one if day } t \text { in lowest quantile of Market_tight } t_{t} \text {, and zero } \\
\text { otherwise }\end{array}$ \\
\hline Total_trans $t$ & Total number of overnight loans granted at day $t$ \\
\hline Total_trans_d $\mathrm{d}_{t}$ & $\begin{array}{l}\text { Dummy variable that equals one if day } t \text { in lowest quantile of Total_trans } s_{t} \text {, and zero } \\
\text { otherwise }\end{array}$ \\
\hline Crisis $_{t}$ & Dummy variable that equals one from 9 August 2007 onwards, and is zero otherwise \\
\hline
\end{tabular}

